\title{
UMA FAMÍLIA DE CULTURA: OS SOUZA CARNEIRO NA SALVADOR DE INÍCIOS DO SÉCULO XX*
}

\author{
Gustavo Rossi
}

Poucos elementos mostram-se tão ricos e expressivos das energias e dos constrangimentos que plasmaram as primeiras etapas da formação cultural e intelectual de Édison Carneiro (1912-1972) quanto a sua própria história familiar e, em especial, a do pai, o engenheiro civil e professor da Escola Politécnica da Bahia, Antônio Joaquim de Souza Car-

Este artigo constitui uma versão modificada e reduzida do primeiro capítulo de minha tese de doutorado, O intelectual feiticeiro: Edison Carneiro e o campo de estudos das relações raciais no Brasil, defendida no Programa de Pós-Graduação em Antropologia Social da Unicamp, em março de 2011. Reafirmo uma vez mais meus agradecimentos a Heloisa Pontes, orientadora da tese, pelas leituras e pelos diálogos decisivos na construção desse trabalho. Sou igualmente grato aos membros da banca examinadora, Mariza Corrêa, Fernanda Peixoto, Sergio Miceli e Antonio Sérgio Guimarães, que arguiram e debateram muitos dos argumentos aqui contidos. Este texto foi discutido ainda em uma reunião do projeto temático "Formação do campo intelectual e da indústria cultural no Brasil contemporâneo", coordenado pelo professor Sergio Miceli, na USP. Deixo, portanto, registrado meus agradecimentos a todo o grupo de pesquisadores e orientandos participantes do projeto, pela seriedade do debate e pela forma com que me ajudaram a refinar muitas das questões apresentadas a seguir. Marilia Giesbrecht, Mariana Françozo e Christiano Tambascia prestaram contribuições importantes lendo e comentando este texto em diferentes momentos de sua criação. Por fim, agradeço Antonio Sérgio Guimarães pelo convite para escrever o artigo e, desse modo, expor alguns dos resultados de minha pesquisa de doutorado. 
neiro (1881-1942). Longe de se resumir a uma mera exumação documental, o levantamento cuidadoso dos eventos pertinentes ao itinerário educacional e profissional de Souza Carneiro possibilita o tratamento de dimensões - de outra maneira - inacessíveis do ambiente de criação e socialização de Edison ${ }^{1}$. Duas delas, em particular, merecem destaque: de um lado, as relações e as modalidades de inserção dos Souza Carneiro nos espaços das elites dirigentes baianas; de outro, em sintonia com a primeira, os efeitos dessas relações nos tipos de identidades sociais e étnico-raciais vivenciadas pela família e, por consequência, nas formas que seus membros tenderam a se apropriar simbolicamente do mundo baiano.

Quando abordadas em conjunto, essas duas frentes de leitura sobre a trajetória de Antônio Joaquim de Souza Carneiro acabam por funcionar como um recurso vigoroso para, num momento seguinte, observamos como essas 82 coordenadas de natureza familiar, política e étnico-racial rebateram, com intensidades variáveis, nos primeiros experimentos intelectuais de Édison Carneiro - notadamente em suas poesias de juventude que, a partir de 1928, quando tinha 16 anos, começaram a aparecer em jornais e periódicos literários de Salvador. Embora tenham pouca importância no conjunto da obra do autor - por ele próprio relegadas ao esquecimento -, tais poesias constituem o que talvez seja um de seus raros escritos de feitio autobiográfico. São narrativas que mobilizaram personagens, valores, sentimentos, geografias e imagens da sociedade baiana que, a todo instante, remetem ao local social de fala do poeta. E, por

1 Édison Carneiro não deixou qualquer escrito de cunho autobiográfico no qual fosse possível apreender relatos, parciais ou sistemáticos, de sua própria trajetória, de suas experiências sociais de infância e juventude, ou, ainda, sobre o ambiente de formação e descobertas de sua "vocação" intelectual. De outra parte, a despeito da recente publicação de uma biografia sobre o autor (Biaggio e Couceiro, 2009), muitas são as lacunas tanto sobre a vida quanto em relação à produção etnográfica e folclórica de Carneiro. Ver, nesse sentido, Rossi (2011). 
isso mesmo, trata-se de uma fonte reveladora das representações que Édison Carneiro fazia de si e das posições ocupadas por ele e sua família na estrutura social da Salvador de inícios do século $\mathrm{XX}^{2}$.

\section{Os Souza Carneiro e seu mundo}

O ambiente de criação e aprendizado cultural de Édison Carneiro, em muito, traz as marcas da situação social instável do pai que, a despeito da posição prestigiada como intelectual polivalente e docente da Escola Politécnica da Bahia, não conseguiu blindar a família de recorrentes momentos de penúria financeira e ameaças de desclassificação social. Em parte, como veremos adiante, essas vulnerabilidades, vivenciadas no plano pessoal e profissional, estiveram sensivelmente atreladas ao próprio equilíbrio instável de poder entre os grupos oligárquicos atuantes na Primeira República baiana, cujo cenário de crise e estagnação econômica acirrava ainda mais as já encarniçadas disputas pelo controle do Estado. Contudo, parafraseando Malinowski (1978), se quisermos infundir carne e espírito a esse esqueleto estrutural de vulnerabilidades e inseguranças que assombra a família de Edison, é indispensável levarmos em conta a individualidade peculiar desse pai: um sujeito de comportamento excêntrico e com uma especial inabilidade para lidar com a administração e os imponderáveis domésticos, agravada ainda por uma viuvez precoce $\mathrm{e}$ um segundo casamento clivado por tensões entre os filhos e a madrasta.

Essa faceta embaraçada no âmbito doméstico parece ter sido a contrapartida de uma vida que buscou fazer da posse e ostentação de suas competências intelectuais e

\footnotetext{
2 Apenas recentemente uma parte da produção poética de Édison Carneiro tornou-se objeto de interesse. Temos uma publicação desse material graças ao esforço de Gilfrancisco dos Santos, que compilou uma série de 31 poemas publicados por Edison em 1928, em Salvador (Santos, 2005).
} 
culturais o arrimo de suas veleidades sociais frente à "boa sociedade” baiana. Souza Carneiro exerceu, com afinco, essa competência nos mais variados gêneros e assuntos: estudos técnicos sobre minérios e geologia; artigos e colunas na imprensa baiana, através dos quais prestava tributo à facção oligárquica a que esteve ligado; ensaios sociológicos e de etnografia afro-brasileira e indígena; romances de motivos regionais e folclóricos; e, até mesmo, trabalhos de cunho esotérico, resultado de sua prática como espírita, maçom e membro de ordens místicas. Esses últimos interesses, inclusive, acabaram lhe rendendo a fama de "bruxo" e "mago" por parte de algumas pessoas que conviveram com ele. Em síntese, trata-se de personagem dos mais intrigantes e que, graças às suas posições, à sua erudição e à sua "prodigiosa capacidade de trabalho" (Carneiro, 1943, p. 320), desempenhou uma influência decisiva no destino social e profissional dos filhos.

Filho de Antônio Joaquim de Souza Carneiro, um engenheiro "mulato", e da "não negra" Rosa Sanches de Souza Carneiro, o também Antônio Joaquim de Souza Carneiro, pai de Edison, foi o primogênito dos quatro filhos do casal. Nascido em 1881, na cidade de Salvador, ainda muito cedo, aos dez anos, ficaria órfão de pai que morreu vítima de um acidente ferroviário no município de Piranhas (AL), onde a família se encontrava por motivos de trabalho do progenitor (Carneiro, 2008) ${ }^{3}$. De fato, é quase impossível remontar a história desse casal, pois tem-se em mãos apenas informações muito vagas: o falecido era filho de um "fazen-

\footnotetext{
3 Apesar das ambiguidades contidas na classificação "não negra", preferi utilizá-la tal como empregada por sua neta, Edíria Carneiro (2008): "não negra" para a avó e "mulato" para o avô. "Não, ela [Rosa Sanches] não era negra [...] O avô, pelos retratos que eu via dele, as feições dele era de um mulato".
} 
deiro português" no Ceará e se formou em engenharia pela Faculdade Politécnica do Rio de Janeiro (Carneiro, 2008). No entanto, é perfeitamente possível especular que o avô de Edison - talvez o resultado da união ou do intercurso de uma negra escrava ou forra e o pai branco português (seu senhor?) - tenha gozado de razoável situação financeira, a ponto de desperdiçar uma temporada de estudos em Coimbra, conforme relatou sua neta:

ele foi pra Coimbra e entrou na malandragem. Então o velho não mandou mais dinheiro, ele teve que voltar e disse: se você não quer estudar, você vai trabalhar na roça igual a um trabalhador. E ele trabalhou uns dias e não aguentou aquilo e disse: não meu pai, quero estudar, aí o pai mandou ele estudar no Rio. Ele se formou em engenharia no Rio (Carneiro, 2008).

Se ele nasceu em Salvador, se ali chegou do Ceará quando pequeno ou somente depois de formado, também é difícil saber. O que parece certo, no entanto, é que fora prática comum entre livres, libertos e descendentes de origem africana se deslocarem de seus lugares de origem como uma forma de, segundo Keila Grinberg,

libertar-se do passado escravo [...] por intermédio da constituição de novas relações sociais. [Afinal], a integração à sociedade dos livres [...] podia ser demorada, e estar num lugar desconhecido poderia ser meio caminho andado no processo de desaparecimento da referência à cor, ou melhor, à condição social (Grinberg, 2002, pp. 47-48).

Ainda mais numa cidade como Salvador que, por meados do século XIX, capital de uma das principais economias do Império, mantinha-se como um polo urbano atraente para um grande número de pessoas de condições jurídicas 
diversas, oferecendo um cenário em que as "indefinições sociais" poderiam jogar a favor dos mestiços que buscavam, através da educação, ascender e se diferenciarem socialmen$\mathrm{te}^{4}$. E embora muito pouco se possa afirmar a respeito da trajetória do avô de Édison Carneiro, é verossímil dizer que ela não foi incomum, tampouco muito divergente daquelas de outros tantos negros e/ou mulatos que, a exemplo do jurista Antônio Pereira Rebouças (1798-1880) e de seu filho André Rebouças (1838-1898), do engenheiro Teodoro Sampaio (1855-1937), do médico Alfredo Casemiro da Rocha (1855-1933), ou do funcionário público e político Manuel Querino (1851-1923), condensavam muitos dos elementos presentes na família de Edison. Os elementos que os credenciavam a melhores chances de mobilidade e ascensão senso de oportunidade, capital de relações e investimentos consideráveis em educação e cultura - tinham o intuito de infundir alguma estabilidade às suas ambições de reco86 nhecimento social e profissional, sujeitas, quase sempre, a contestações em decorrências da origem ou das "raças" dessas famílias ${ }^{5}$.

\footnotetext{
4 Na Salvador de meados do século XIX, "se confundiam escravos, libertos e livres; muitos, inclusive, com alguma astúcia e bastante senso de oportunidade, poderiam encontrar uma forma de reverter as condições sociais nas quais se encontravam, fosse negando a escravidão, fosse logrando ingressar no universo dos homens livres, fosse [...] buscando a diferenciação social na educação" (Grinberg, 2002, p. 57). Segundo Maria Alice Resende de Carvalho, os estratos mestiços da sociedade baiana conheceriam possibilidades maiores de ascensão, sobretudo, nos momentos posteriores à Independência do Brasil, a partir de 1822, "quando, desalojados os portugueses que mantinham os privilégios comerciais dos tempos da colonização, a praça de Salvador e toda a economia do Recôncavo viram florescer uma sociedade mestiça, educada e especificamente urbana, composta por comerciantes, clérigos, militares, funcionários e profissionais liberais” (1998, p. 68).

5 Sobre a família Rebouças, ver Carvalho (1998; 2007), Sptizer (2001) e Grinberg (2002). Sobre o médico baiano Alfredo Casemiro da Rocha, ver Nogueira (1992). Quanto a Manuel Querino, ver Guimarães (1973) e Guimarães (2004b). Sobre Teodoro Sampaio, ver Costa (2007) e Lopes (2004). Vale notar que todos eles eram, além de nascidos em território baiano, filhos ou apadrinhados de homens brancos de posses e/ou "respeitáveis", fato que se mostrou decisivo em seus itinerários sociais e profissionais.
} 
Seja como for, quais fossem os caminhos que o levaram à capital baiana, foi ali que o avô de Édison Carneiro conseguiu prosperar econômica e profissionalmente. Após morte precoce, em que deixou quatro filhos em idade escolar, sua esposa, Rosa Sanches - pouco tempo depois de enviuvar -, contraiu segundo casamento com o igualmente engenheiro e "amigo da família", Aluízio Ramos Accioly. A partir de então, Accioly assumiria a tutela das crianças e o controle do espólio financeiro deixado pelo falecido ${ }^{6}$ : entre os imóveis (uma casa e uma roça na Freguesia da Penha), e "cadernetas de poupança de iguais valor [sic] aos seus quatro filhos", chegava-se a uma soma considerável de 33 contos de réis ${ }^{7}$.

No limite, a figura de Ramos Accioly resulta tanto ou mais misteriosa quanto a do próprio falecido Souza Carneiro. No entanto, ao que tudo indica, mesmo não sendo homem de maiores posses, sua formação e atuação como engenheiro teria lhe permitido acumular prestígio e boas relações, contribuindo para que os filhos de Rosa Sanches frequentassem algumas das melhores instituições de ensino particulares, destinadas à formação dos rebentos da classe dirigente baiana. $\mathrm{O}$ percurso educacional das quatro

6 Ver Arquivo Público do Estado da Bahia (APEBa), Seção Judiciária, Série Inventários e Testamentos, Antônio Joaquim de Souza Carneiro, Ano 1909, Documento 07/3126/16. Não se sabe ao certo quando Ramos Accioly e Rosa Sanches se casaram. Contudo, um relatório escrito pelo próprio Accioly, anexado ao inventário, aponta que, já em 1891, ele estava cuidando da educação das crianças. O primeiro marido de Rosa Sanches faleceu em 21 de janeiro de 1891. A fim de facilitar o andamento e a inteligibilidade do texto, todas as fontes consultadas em arquivos serão mencionadas em nota de rodapé.

7 Ver APEBa, Seção Judiciária, Série Inventários e Testamentos, Antônio Joaquim de Souza Carneiro, Ano 1892, Documento 05/1826/2297/12. Jeferson Bacelar, trabalhando com séries de inventários e testamentos do Arquivo Público do Estado da Bahia, para os anos de 1889 a 1919, estabelece a casa dos 50 contos de réis como critério dos "possuidores de pequenas fortunas" (2001, p. 56). Tal marca também foi estabelecida por Kátia de Queirós Mattoso (1992). Ainda, segundo Bacelar, 200:100\$000 de réis poderia ser tomado como critério do "grupo de indivíduos incluídos no rol dos realmente ricos da cidade [Salvador]” (2001, p. 56). 
crianças de Rosa Sanches (Antônio Joaquim, José Joaquim, Adília Rosa e Edgar Sanches) mereceu o registro minucioso do padrasto, uma vez que, ao atingirem a maioridade, seus pupilos o acusaram de usar indevidamente o dinheiro da herança paterna. Intimado judicialmente a prestar contas da tutela, em agosto de 1909, Ramos Accioly redigiu um copioso relatório de defesa, no qual buscava justificar seus gastos e suas movimentações financeiras com a educação dos jovens.

José Joaquim, o segundo mais velho, nascido em 1883, após um ano como interno no Colégio Carneiro Ribeiro, foi enviado ao Colégio Sete de Setembro,

recomendando-o $[\ldots]$ ao seu diretor, senhor Dr. Luiz da França Pinto de Carvalho. Três meses depois de sua entrada nesse colégio, dizia-me o emérito mestre que não o expulsava da casa em atenção a mim, por corresponder no empenho que eu manifestava com tanto ardor para que o menino estudasse, mas que era perder tempo e dinheiro ${ }^{8}$.

Teria sido apenas "do terceiro ano em diante" que José Joaquim, "dando-se por vencido", começou a estudar mais seriamente para, em seguida, cursar a Faculdade de Direito da Bahia, onde se formou em 1908. Já Adília Rosa, de 1886, mesmo padecendo "desde a idade de dois anos, de uma paralisia infantil, que a privava do uso dos membros inferiores do corpo", recebeu o diploma de "aluna-mestra”, em 1905, no Instituto Normal. Segundo Ramos Accioly, "foi dentre os quatro irmãos, o único bom estudante". Edgar Sanches, o caçula, vindo ao mundo em 1888, passou "dez anos consecutivos nos colégios Spencer e São Salvador” e, em

\footnotetext{
8 APEBa, Seção Judiciária, Inventários e Testamentos, Antônio Joaquim de Souza Carneiro, Ano 1909, Documento 07/3126/16; grifos nossos.

9 APEBa, Seção Judiciária, Inventários e Testamentos, Antônio Joaquim de Souza Carneiro, Ano 1909, Documento 07/3126/16.
} 
1909, encontrava-se no segundo ano do curso jurídico da capital baiana ${ }^{10}$.

Em nada diferente dos outros irmãos, Antônio Joaquim de Souza Carneiro parece ter se beneficiado da condição de enteado de Ramos Accioly, a qual talvez servisse para contrabalancear a irregularidade do primogênito nos estudos:

O mais velho, de nome Antônio, antes mesmo de ser seu tutor, pouco depois de sua chegada a esta capital [Salvador], em 1891, internei-o no Colégio São José, passando-o no ano seguinte para o Colégio Carneiro, e deste para diversos professores [...] para ensiná-lo a estudar, por ser ele pouco aplicado [...]. Por fim, internei-o no Colégio Spencer, de onde saía todos os dias para frequentar as aulas da Escola Politécnica como aluno adido, sujeito ao pagamento de matrícula nessa escola. Fui forçado a mandálo a Aracaju a fim de [documento rasgado] os preparatórios. Frequentou a Escola Politécnica durante sete anos e recebeu o diploma de engenheiro civil em 1905 [...] Devo muito aos lentes desta escola, em particular ao meus amigos Srs. Alexandre Maia e Arlindo Fragoso, muita gratidão pelo que fizeram em favor de Antônio ${ }^{11}$.

É difícil saber o que há de verdade nas palavras do padrasto quanto ao desempenho deficiente dos afilhados. Preocupado em convencer o Juiz de Órfãos de Salvador de seus esforços e de sua inocência, é quase certo que Ramos Accioly buscasse inflacionar a importância de sua tutela. Contudo, essa inflação em nada invalida a hipótese de que as amizades e a boa reputação do padrasto tenham, de fato, contribuído para o sucesso escolar dos quatro enteados.

\footnotetext{
${ }^{10}$ APEBa, Seção Judiciária, Inventários e Testamentos, Antônio Joaquim de Souza Carneiro, Ano 1909, Documento 07/3126/16.

${ }^{11}$ APEBa, Seção Judiciária, Inventários e Testamentos, Antônio Joaquim de Souza Carneiro, Ano 1909, Documento 07/3126/16; grifos nossos.
} 
Afinal, na virada dos séculos XIX e XX, numa sociedade recém-liberta do trabalho escravo, não deviam ser poucos os obstáculos e os constrangimentos a que estavam expostos os raros negros e mestiços que tiveram condições de aspirar a uma vaga nos estabelecimentos de ensino de elite. De modo que, a despeito das reconhecidas competências ou das efetivas condições financeiras para custear os estudos, boas relações, proteções ou filiações pareciam ser decisivas para que tais aspirações não fossem brutalmente bloqueadas (Azevedo, [1953] 1996) ${ }^{12}$.

Infelizmente não foi possível esmiuçar a procedência dos laços entre Ramos Accioly e, em particular, os docentes da Escola Politécnica da Bahia, os quais teriam atuado em favor do pai de Édison Carneiro. No entanto, quaisquer fossem os móveis desses laços, eles foram fortes o suficiente para que Antônio Joaquim de Souza Carneiro os mobilizasse como parâmetro de suas futuras tomadas de posição 90 junto às facções oligárquicas locais. Uma série de pistas, dentre as quais o relatório de Ramos Accioly é a primeira,

12 Na falta de fontes ou indícios mais precisos que dão conta da passagem dos Souza Carneiro pelos colégios e pelas faculdades que cursaram, podemos apenas imaginar - controladamente - o que teriam sido tais experiências nesses estabelecimentos, imersos num ambiente de relações em que a cor e a origem não estavam imunes aos riscos de se converterem em motes de estigmas, conflitos, recusas ou isolamentos. Trata-se de uma situação de vulnerabilidade e violência simbólica que devia exigir jogo de cintura e senso aguçado nas negociações travadas naqueles espaços, a fim de que os marcadores raciais não monopolizassem as representações de suas identidades sociais. Decerto, tem-se um intento delicado e, quase sempre, apenas parcialmente logrado (quando não, simplesmente fracassado), como bem revelam, por exemplo, as experiências universitárias do médico baiano estudado por Oracy Nogueira, Alfredo Casemiro da Rocha (1855-1933), e do escritor carioca Lima Barreto (1881-1922). Ainda que em períodos e lugares distintos, ambos mostram-se casos expressivos dos constrangimentos e sentimentos de intimidação raciais a que estavam expostos os indivíduos negros e mestiços nos estabelecimentos de ensino superior brasileiros em finais do século XIX (Nogueira, 1992; Barreto, 1998). De modo que, talvez, faça sentido dizer que muitas das "atenções" e das "gratidões" invocadas pelo padrasto Ramos Accioly possam também ser lidas como registros cifrados de intercessões de seus amigos, diretores e professores, para amortecer eventuais tensões de natureza racial envolvendo os jovens da família Souza Carneiro. 
sugere que Souza Carneiro gozou de proteções e auxílios dos amigos do tutor, especialmente as de Arlindo Coelho Fragoso (1865-1926). Sem dúvida, tal condição deve ter influenciado decisivamente a vida social e profissional de Souza Carneiro, ainda mais quando se têm em vista as credenciais do "protetor" que, de forma alguma, podem ser minimizadas.

Formado em engenharia no Rio de Janeiro, duas vezes deputado federal pela Bahia, diretor da Secretaria da Agricultura no governo de Luís Vianna (1896-1900) e principal responsável pela criação da Escola Politécnica do estado, em 1896, onde foi seu primeiro diretor entre os anos de 1897 e 1908, Arlindo Fragoso emprestou muito de sua autoridade acadêmica e política para essa instituição. Inclusive, foi graças à atuação de Fragoso que, pondo "em campo todo o seu prestígio" (Sem autor, [1923] 2004, p. 463) ${ }^{13}$ como Secretário Geral do Estado no governo de José Joaquim Seabra (1912-1916), a Politécnica adquiriu a sua sede permanente, em 1915, com a compra de um "palacete" no largo São Bento. Neste mesmo período, Fragoso foi um dos engenheiros responsáveis pela criação e execução do projeto de remodelação urbana de Salvador, cujo plano diretor pretendia não apenas sanear e higienizar o centro da capital, mas também amenizar sua arquitetura colonial, conferindo-lhe uma fachada mais "moderna" e "civilizada" (Pinheiro, 2002). Com uma carreira das mais vigorosas entre os quadros políticos e intelectuais da Primeira República na Bahia, deveu-se ainda à intervenção de Arlindo Fragoso a fundação, em 1917, de uma instituição que, ao lado do Instituto Histórico e Geográfico, foi central na organização da vida cultural local: a Academia de Letras da Bahia, para a qual "redigiu e assinou todas as cartas aos intelectuais que deviam compor

\footnotetext{
${ }^{13}$ Em seguida a Arlindo Fragoso, o segundo diretor da Escola Politécnica (entre 1908 e 1912) foi o outro "amigo" do tutor, o engenheiro Alexandre Maia Bittencourt, um dos "sócios fundadores" da instituição (Sem autor, [1923] 2004, p. 462).
} 
o quadro da Academia. Escolheu os quarenta patronos e os ocupantes das respectivas cadeiras" (Alves, 1977, p. 75).

Ora, diante de tão prestigiada figura pública, na ocasião de sua morte, em janeiro de 1926, não seria surpresa que as homenagens prestadas a Arlindo Fragoso ficassem a cargo de alguém muito próximo do proeminente falecido e, porque não, um dileto ou discípulo seu: alguém reconhecido enquanto tal pelo corpo docente da própria faculdade que ele havia fundado. De modo que, nas "grandes homenagens" da Escola Politécnica à memória de seu fundador, Souza Carneiro "foi unanimamente escolhido por seus pares [...] para estudar a individualidade do Dr. Arlindo Fragoso, sob seus múltiplos aspectos - engenheiro, professor, orador, administrador, crítico [e] jornalista" ${ }^{14}$.

Não saberíamos dizer quando a biografia encomendada foi entregue. No entanto, na edição de 1942 da Revista da Academia de Letras da Bahia, podemos ler um artigo de Souza

92 Carneiro que corresponde bastante aos objetivos do referido "estudo" - ou ao menos parte dele. Trata-se de um retrato admirado e emocionado do "mestre" Arlindo Fragoso:

Eminentes colegas da Escola [...] Quando me honrastes em ser vosso intérprete, escolhendo-me arauto de vossas manifestações de gratidão ao que Arlindo Fragoso foi para a Escola Politécnica, me envolvestes num banho de luz, obrigando-me a falar sobre a individualidade de moço, de crítico, de artista, político, de jornalista; - de Arlindo em sua feição multiforme de homem público, e discípulo, e mestre, e amigo, e criador; - de Arlindo em seu extraordinário talento, em sua maravilhosa condição de literato, e cientista, e engenheiro [...] Aqui estou no desempenho dessa missão [...] seguro da incumbência, por ele mesmo deixada, de ser o seu

\footnotetext{
${ }^{14}$ Biblioteca Pública do Estado da Bahia (BPEBa), "As grandes homenagens da Escola Politécnica”, Diário da Bahia, Salvador, 21 jan. de 1926, p. 1.
} 
biógrafo nas linhas que redigi para agora, que rendemos a seus feitos, a eternidade de nossos corações (Souza Carneiro, 1942, pp. 345-346; grifos nossos).

A suposta confiança de Arlindo Fragoso no discípulo, a ponto de, em vida, atribuir-lhe pessoalmente a "missão" de redigir sua biografia, é constantemente ressaltada no texto. Souza Carneiro chega a afirmar que Fragoso teria considerado indicá-lo para uma das cadeiras da Academia de Letras da Bahia. Tal indicação, o pai de Edison viu-se obrigado a humildemente recusar, uma vez que o próprio Fragoso, fundador da agremiação, correria o risco de ficar sem lugar entre os imortais locais: "escolhe [para a Academia de Letras] quarenta nomes que realmente figuram na consciência sua, mas a política deve ser atendida, as amizades devem ter um lugar com as inimizades, as conveniências devem jogar com o conceito. [Então] cedo-lhe o lugar que me destinou" (Souza Carneiro, 1942, p. 362; grifos nossos) ${ }^{15}$.

Decerto, seria preciso enxergar com ressalvas o modo como Antônio Joaquim Souza Carneiro invocava o espólio de Arlindo Fragoso a fim de se apropriar das virtudes do ilustre falecido. Contudo, é impossível duvidar da existência de fortes sentimentos de afeição e respeito mútuos entre Souza Carneiro e Fragoso. Afinal, embora herdada como uma espécie de bem de família, a relação foi sancionada pública e academicamente pelos próprios membros da faculdade que Arlindo havia ajudado a criar. Essa relação, cujas vantagens nem sempre resultaram em ganhos materiais, teve rendimentos simbólicos substantivos, espe-

\footnotetext{
${ }^{15}$ Embora seja possível que o convite tenha sido feito por Arlindo Fragoso, o mais provável é que Souza Carneiro ficasse sem nenhuma vaga, não pela sua recusa, mas por questões outras: as cadeiras da Academia de Letras da Bahia estavam sendo usadas por Fragoso, como o próprio pai de Edison deixa entrever, para amortecer uma série de choques advindos das brigas políticas locais. Fragoso procurava um equilíbrio entre membros de diferentes grupos oligárquicos, bem como entre os nomes brasonados da elite local. Ver, neste sentido, Jorge Calmon (s.d.).
} 
cialmente no que diz respeito à qualidade e ao volume de capital social a ela atrelados: possibilitou a Souza Carneiro chances melhores, novas proteções, empregos, postos na imprensa, apadrinhamento dos filhos e até mesmo uma carreira política. Porém, tão importante quanto, trata-se de uma rede de relações que, articulada aos seus trunfos educacionais e às suas competências culturais, ajudou a informar as percepções de localização e pertencimento social e étnico da família Souza Carneiro.

Importa, por ora, chamar a atenção para a forma como o apadrinhamento se mostra uma evidência eloquente para se entender os tipos de lealdade política que estiveram na base da existência social dos Souza Carneiro: eram membros de uma elite sem tostão, cujas distinções mais significativas tendiam a se realizar justamente a partir das fidelidades e prestações de serviços aos clãs familiares e às facções oligárquicas no poder ou na oposição da política local. Tendo 94 em vista o baixo grau de diferenciação da estrutura social baiana, organizada basicamente pelos serviços vinculados à produção agroexportadora - retraída desde os tempos do Império -, e ao crescimento da máquina burocrática, as lealdades políticas, já observou Consuelo Novais Sampaio, constituíam um dos mecanismos centrais através dos quais diferentes segmentos urbanos "concretizaram aspiração social, integrando-se ao pequeno universo das classes dirigentes" (Sampaio, 1998, p. 41).

Tal situação não seria diferente daquela vivenciada pelo pai de Édison Carneiro e sua família, cujas ambições sociais e profissionais estiveram sensivelmente condicionadas aos sucessos e fracassos das facções políticas apoiadas pelo padrasto e por Arlindo Fragoso, nas quais se destacava a liderança inconteste de José Joaquim Seabra (1855-1942). Para correligionários dedicados como foram os Souza Carneiro, certamente não faltaram oportunidades e meios para que J. J. Seabra pudesse recompensá-los no correr de seus notá- 
veis doze anos de controle ininterrupto sobre a engrenagem política baiana, entre 1912 e 1924: período em que se elegeu duas vezes governador (1912-1916 e 1920-1924), bem como fez seu sucessor, seu homem de confiança Antônio Moniz Sodré de Aragão, para o mandato de 1916-1920. Com sólidas relações no âmbito federal, personalidade carismática "insofismável" e "visão realista do poder", Seabra soube não apenas se ajustar e tirar proveito das fundas dissidências oligárquicas disseminadas por todo o estado, "domesticando os coronéis" (Sampaio, 1998, pp. 129 e ss.) ${ }^{16}$, mas também cativar números expressivos de seguidores fiéis entre diferentes segmentos da sociedade baiana: em especial, entre os grupos urbanos de Salvador, espaço social no qual, segundo o historiador Cid Teixeira, a "raposa" Seabra inaugurou

nos costumes políticos da Bahia [...] uma coisa que até então era desconhecida: o comício, o apelo direto ao povo [...] O primeiro a reunir o povo na rua, [a] usar todo o seu carisma diretamente à multidão [...] que o vai cristalizando como um líder a partir da capital, na conveniência e na troca do apoio com o coronelismo, com o poder do sertão (Teixeira, 1988, p. 42) ${ }^{17}$.

Com certeza, em muitos desses comícios, mas também nas recepções, nas homenagens e nos jantares dedicados a J. J. Seabra, estiveram presentes Antônio Joaquim e demais membros da família Souza Carneiro, que prestavam todo o seu apoio ao glorioso chefe. Esse apoio, incondicional e de longa data, ao fim, se mostrou decisivo para a realização da

\footnotetext{
${ }^{16}$ Antes de ser governador da Bahia, Seabra fora ministro em duas diferentes presidências: ocupou a pasta do Ministério do Interior e Justiça durante o governo de Rodrigues Alves (1902-1906) e, depois, a da Viação e Obras Públicas, entre 1910 e 1912, na presidência de Hermes da Fonseca (1910-1914).

${ }^{17}$ Sobre José Joaquim Seabra e seu domínio político, ver Sampaio (1998), Quaresma (1999) e Sarmento (2008).
} 
carreira política do irmão mais velho de Edison, o futuro senador da República Nelson Carneiro (1910-1996). Não por acaso, foi esse último, dentre os membros da família, aquele quem forneceu um dos registros mais expressivos da gravidade que revestia as atitudes da família para com o "chefe" Seabra:

éramos seabristas de três gerações, dos que não abandonaram o glorioso chefe [...] Seguia assim a trilha normal, que eu próprio preferira três anos antes, quando naquela madrugada de 1926 [...], J. J. Seabra, a quem meu tio me apresentava, me comoveu: "Um Souza Carneiro não degenera" (Carneiro, 1990, p. 55; grifos nossos).

Em síntese, para essa família sem condições de agenciar posses ou símbolos de distinção histórica e tradicionalmente valorizados pela sociedade baiana - propriedades 96 rurais, fortuna, origem familiar, ancestralidade nobiliárquica, antiguidade no mando político ou mesmo uma branquitude acima de qualquer suspeita - e cuja ocupação do pai como catedrático da Politécnica era a única fonte regular de renda, é bastante provável que a boa administração de seus estoques de relações fosse central para a manutenção e reprodução de suas posições. De modo que é possível afirmar que as lealdades políticas e a polivalência intelectual, e a busca por uma afirmação, antes de qualquer coisa, como homem de "honra", "inteligência", "leal" e "de cultura", foram alguns dos principais trunfos mobilizados por Antônio Joaquim de Souza Carneiro na tentativa de assegurar melhores posições no interior da classe dirigente baiana.

\section{A morte "branca" do engenheiro "mulato" Antônio Joaquim de Souza Carneiro}

Antônio Joaquim, ao que tudo indica, se casou com a "mulata" Laura Coelho de Souza Carneiro logo depois de 
concluir o curso de engenharia civil, uma vez que o primeiro filho do casal, Franklin, nasceu em junho de $1907^{18}$. O rebento foi o primeiro de uma leva de mais seis: Milton de Souza Carneiro, em abril de 1909; Nelson de Souza Carneiro, em abril de 1910; Édison de Souza Carneiro, em agosto de 1912; Ivan de Souza Carneiro, em março de 1914; Miriam Stella de Souza Carneiro, em setembro de 1920; e, finalmente, Carmen Lídia de Souza Carneiro, em fevereiro de $1922^{19}$. O casamento também coincidiu com o início precoce da carreira universitária de Souza Carneiro que, dando provas de sua competência e de suas boas relações com Arlindo Fragoso, então diretor da instituição, assumiu a cátedra de Geologia apenas um ano depois de se formar, já em 1905. Isso numa instituição, como lembra Thales de Azevedo nos anos 1950, que antigamente "dificultava [...] a admissão de alunos de cor” ([1953] 1996, p. 131). Essa situação não fora menos verdadeira para o recrutamento de seu professorado; era possível, porém, transpor o bloqueio, uma vez que, ainda segundo Azevedo, teriam sido "homens de cor" mais "de um diretor da escola" ([1953] 1996, p. 131) ${ }^{20}$.

Nos anos seguintes à sua efetivação na Politécnica, Souza Carneiro se dedicou com afinco ao ensino das disciplinas de geologia e áreas afins e ao estudo da diversidade natural e mineral do estado da Bahia. O esforço resultaria numa primeira leva de trabalhos técnicos que colocaria seu nome em evidência na vida pública e intelectual brasileiras.

\footnotetext{
${ }^{18}$ Aqui, mais uma vez, valho-me de Edíria Carneiro (2008) como informante: "O pai de Edison é que casou com uma mulata”.

${ }_{19}$ APEBa, Seção Judiciária, Série Inventários e Testamentos, Antônio Joaquim de Souza Carneiro, Ano 1943, Documento 05/2300/2800/06. O casal teve mais um filho, Philon, poucos anos mais novo que Édison, mas que morreu em 1940.

${ }^{20}$ Um deles a quem Thales de Azevedo se refere certamente é o próprio Souza Carneiro que, por volta de 1908, assumiu temporariamente a direção da Escola. Nesse ínterim, Arlindo Fragoso cuidava dos preparativos para a construção do pavilhão da Bahia na Exposição Nacional de 1908, no Rio de Janeiro (Souza Carneiro, 1942, p. 360).
} 
Entre os trabalhos mais significativos estão algumas pequenas monografias sobre variedades de mamíferos, insetos, moluscos, madeiras "de construção" e toda espécie de plantas oleíferas e medicinais. Destaca-se especialmente o volume Riquezas minerais do estado da Bahia (1908), estudo que rendeu ao autor o Grande Prêmio da Exposição Nacional de 1908, realizada no Rio de Janeiro como parte das comemorações do centenário da abertura dos portos brasileiros (Carneiro, 1943, p. 319).

A partir de 1912, com a eleição de J. J. Seabra e a convocação de Arlindo Fragoso para a Secretaria Geral do Estado, Souza Carneiro, professor laureado e de reconhecido saber, recebeu as primeiras indicações para os cargos comissionados que ocupou: "Engenheiro-Chefe da Comissão Geográfica e Geológica do Estado, Chefe de Estudos da Rede Baiana de Ferro" e, por fim, "Superintendente dos Serviços de Gás e Eletricidade de Salvador" (Carneiro, 1943, p. 320). Mesmo com o acúmulo de tarefas, nesse mesmo contexto Souza Carneiro foi enviado para o Rio de Janeiro, em 1913, como representante da Bahia na Exposição Nacional da Borracha, ocasião em que seria novamente recompensado, dessa vez, com o Grande Prêmio do Ministério da Agricultura por seus trabalhos $A$ borracha no estado da Bahia, A indústria da borracha no Brasil e a "brochura para a divulgação no estrangeiro", Rubber in Brazil - os três publicados em 1913 (Carneiro, 1943, p. 320) ${ }^{21}$.

Contudo, mesmo com o posto na Escola Politécnica e a

${ }^{21}$ Foram esses "primeiros vinte anos de sua vida pública", entre 1905 e 1925, um dos períodos mais fecundos da carreira acadêmica e científica de Souza Carneiro, e resultaram numa série de trabalhos, tais como: Limites intermunicipais; o "estudo de ecologia", A pesca da baleia; as "monografias descritivas", A cachoeira de Paulo Afonso e O morro de Santo Antônio; e os "trabalhos de divulgação para os Estados Unidos", Cooper in Brazil, Manganese in Brazil e Mineral resources of the State of Bahia; e ainda outras monografias e relatórios sobre a bacia do rio São Francisco e a "argila plástica do Retiro" (Carneiro, 1943, p. 320). O artigo de Édison Carneiro não faz menção às datas específicas de produção ou publicação desses trabalhos do pai. 
atuação nos demais cargos comissionados, a família numerosa não permitia maiores folgas financeiras ao professor. Em parte, isso explicaria as tentativas, todas frustradas, de Souza Carneiro de abrir novas frentes de renda, especialmente a partir de 1918, quando já havia nascido o quinto filho e três deles encontravam-se em idade escolar. Para esse período, existem algumas escrituras de contratos firmados por Souza Carneiro relacionados com a exploração e comercialização de manganês em território baiano. Mas o reconhecido saber técnico que ele tinha sobre a exploração de minérios não devia ser o mesmo para os negócios. Por razões desconhecidas, além de ter rompida sua sociedade com certo "senhor Doutor Demétrio Urpia”, viu-se ainda judicialmente obrigado a ceder os eventuais lucros provenientes da negociação do manganês extraído em razão das dívidas não cumpridas, que alcançavam a considerável quantia de 20 contos de réis entre despesas com "pessoal, freteiros [e] transportadores"22. Desfeitas as expectativas de fazer dinheiro no setor minerador, Souza Carneiro buscou, sem sucesso, uma colocação como docente no Ginásio da Bahia, em 1921. Tentaria, ainda, mais uma vez no ano seguinte, repetindo o resultado: "apresenta-se novamente o Dr. Antônio de Souza Carneiro candidato ao concurso da seção de matemática [...] Em cinco reuniões da congregação leu o Dr. [Luis Anselmo da] Fonseca o parecer, de que foi relator, inabilitando o candidato. Posto em discussão, o parecer foi aprovado por unanimidade" (Farias, 1937, p. 287). Por fim, Souza Carneiro desistiu de buscar novas ocupações, ficando unicamente com o ensino na Escola Politécnica e com as eventuais rendas advindas dos cargos por indicação e de suas colaborações na imprensa.

22 APEBa, Seção Judiciária, Livro de Notas da Capital, Livro 86, folha 14, Ano 1918-1919. Outras referências sobre os mal-sucedidos negócios de Souza Carneiro podem ser encontradas em APEBa, Seção Judiciária, Livro de Notas da Capital, Livro 230, Ano 1918, folhas 8, 9 e 21. 
Os momentos de dificuldade, no entanto, devem ter se agravado mais seriamente a partir de 1924, quando finalmente, após longos doze anos, os grupos rivais de J. J. Seabra conseguiram derrubá-lo do poder. Enfraquecido com a derrota de sua candidatura à vice-presidência na chapa com Nilo Peçanha, em 1922, e já fragilizado internamente pelos ataques constantes que vinha sofrendo de uma forte oposição articulada por duas tradicionais famílias no mando político da região, os Calmons e os Mangabeiras, José Joaquim Seabra conhecera não apenas a impopularidade, mas também uma derrota fulminante que praticamente encerrara sua carreira política no estado (Sampaio, 1998, pp. 164-169). A reconfiguração do poder local, com a ascensão de Francisco Marques de Góis Calmon (1924-1928) ao executivo baiano, teria efeitos quase que imediatos na vida de Souza Carneiro e outros tantos seabristas de "três gerações" (Carneiro, 1990, p. 55), lançados em um ambiente hostil 100 que se seguiu à posse do novo governador. Desde então, passou a existir

uma dicotomia completa, um maniqueísmo absoluto na política baiana: ou se é seabrista ou [...] calmonista [...] E [...] realmente, a partir de 1924 até 1930 , o que existe na Bahia [...] é uma disputa de suas estruturas oligárquicas [que] vai se caracterizar por derrubadas, perseguições, perdas de mando, ascensão de valores novos, por mil coisas que vão significar a polarização das forças (Teixeira, 1988, p. 47).

Por essa época, em virtude das atitudes firmes de Souza Carneiro, agora como "homem de oposição, [que] não se amedrontava jamais" (Amado, 1981), inúmeras passaram a ser as dificuldades, agruras e "privações que a família do velho professor de geologia foi obrigada a curtir, por perseguições de um governador que não perdoava os 
adversários" (Ferraz, 1972) ${ }^{23}$. Os efeitos das oscilações da política baiana só não foram mais drásticos em termos do rebaixamento social de Souza Carneiro e seus filhos graças à intervenção de seu irmão mais novo, o advogado José Joaquim, que "era o rico da família" e tinha acumulado um bom dinheiro em Ilhéus, trabalhando para as novas fortunas dos "fazendeiros do cacau": foi ele "quem custeou os estudos desses sobrinhos [...] quem aguentou as pontas" (Carneiro, 2008). De modo que, a despeito das dificuldades enfrentadas naquele momento, todos os filhos conseguiram finalizar com sucesso as etapas educacionais necessárias para se diplomarem nas instituições de ensino superior baianas. Entre os filhos homens, dois seguiram a tradição familiar e se formaram engenheiros na Escola Politécnica (Milton e Ivan); enquanto os outros três, bacharéis, se diplomaram pela Faculdade de Direito da Bahia (o primogênito Franklin, Nelson e Edison). Já as mulheres, Miriam Stella e Lídia, se tornaram professoras, após cursarem as duas únicas instituições públicas destinadas ao ofício: o Instituto Normal e o Ginásio da Bahia que,

\footnotetext{
${ }^{23}$ Para piorar a situação, Souza Carneiro enviuvou e, em 1925, se casou novamente com certa Georgina Rocha, passando também a arcar com as despesas dessa segunda relação. Georgina, que já era mãe de dois filhos, não teria tido boas relações com os enteados. Desse modo, não surpreende que os registros deixados por amigos de Édison Carneiro façam recorrentes menções à penúria financeira da família, funcionando sempre como um contraponto para se evidenciar as qualidades de Souza Carneiro como "homem de cultura", que fazia da erudição o meio e o fim de sua existência pessoal e social. Um "homem ilustre", porém "pobre, vivendo com as dificuldades que cercam os que fazem da cultura sua meta" (Amado, 1981). Em seu volume de memórias, Jorge Amado também menciona as dificuldades materiais da família de Édison Carneiro, o qual é retratado como sendo, na época, o "mais pobre de todos nós" (1992, p. 426). Sobre Laura Coelho de Souza Carneiro não foi possível obter maiores informações, mesmo entre os familiares, talvez, por ter morrido precocemente, em algum momento entre 1922, quando teve seu último filho, e 1925, ano em que Souza Carneiro se casou com Georgina Rocha. Ver APEBa, Seção Judiciária, Série Inventários e Testamentos, Antônio Joaquim de Souza Carneiro, Ano 1943, Documento 05/2300/2800/06. Quanto às relações pouco amistosas entre Georgina Rocha e os enteados, elas foram mencionadas por Edíria Carneiro (2008).
} 
desde 1918, oferecia a cadeira de "pedagogia", formando "bacharelas" para o ensino primário ${ }^{24}$.

A situação social e financeira de Souza Carneiro jamais conheceu melhoras significativas. Muito pelo contrário, o seabrismo cada vez mais imoderado do professor rendeu-lhe ainda um dos mais fortes golpes sofridos em vida: o desligamento da Escola Politécnica, em 1932, ao ser "aposentado à força, sem mais nem menos, por motivos políticos" (Carneiro, 1943, p. 320; grifos nossos). O desligamento se deu como resultado dos esforços empreendidos pelo então recém-empossado interventor Juracy Magalhães para sufocar quaisquer pretensões de J. J. Seabra - bem como as de outras forças oligárquicas locais - em assumir as rédeas do processo revolucionário na Bahia, perseguindo e prendendo seus principais correligionários (Magalhães, 1982). E como o seabrismo era um negócio de família entre os Souza Carneiro, naquele mesmo ano Nelson Carneiro, já despon102 tando como uma jovem e promissora liderança de oposição ao interventor "estrangeiro" indicado por Vargas, também seria acossado e, posteriormente, preso e deportado para o Rio de Janeiro. Sem o emprego na Escola Politécnica e com a família seriamente desestruturada, Souza Carneiro seguiria para o Rio de Janeiro para se juntar ao filho Nelson. Ali, dando provas de que seu prestígio acadêmico não havia se esvaído inteiramente, conseguiu obter a cátedra de estatística na Faculdade de Ciências Econômicas, da Universidade do Distrito Federal ${ }^{25}$. No entanto, a experiência carioca não duraria muito. Por volta de 1937, já estava Souza Carnei-

\footnotetext{
${ }^{24}$ APEBa, Seção Judiciária, Série Inventários e Testamentos, Antônio Joaquim de Souza Carneiro, Ano 1943, Documento 05/2300/2800/06. Sobre o Ginásio da Bahia, ver Farias (1937, p. 273).

${ }_{25}$ Ao que consta, na história da universidade carioca o "primeiro professor de estatística de que se tem notícia foi Antônio Joaquim de Souza Carneiro [...] Esse professor, em 20 de março de 1934, assinou o termo de posse de substituto da cadeira de Política Comercial e Regime Aduaneiro. Em 27 de novembro de 1934, passou à "catedrático de estatística”" Pardal (2001).
} 
ro de volta à Bahia, embora fosse obrigado a esperar mais alguns anos para reaver a vaga na Escola Politécnica, ocupada novamente por pouco tempo, antes de sua morte, em 1942, e sem a qual ele "ficou reduzido a quase nada" (Carneiro, 1943, p. 320).

As turbulências sociais e políticas foram vivenciadas por Souza Carneiro em dois momentos: o primeiro, na ocasião da derrota dos grupos oligárquicos que davam suporte às suas ambições, e o segundo, com a Revolução de 1930, que desmantelou a própria estrutura do poder baiano que permitia a atuação desses grupos. Ambos evidenciam o campo restrito de opções oferecidas a Souza Carneiro para enfrentar as ameaças de desclassificação social que se mostravam cada vez mais dramáticas e irremediáveis. Em grande medida, o velho professor dependia, de um lado, de condições favoráveis para que fizessem valer seus serviços e suas lealdades políticas e, de outro, do investimento em práticas capazes de simbolizar sua condição de acadêmico e erudito. Contudo, derrotado politicamente e, por consequência, diminuídas, e, mais tarde, bloqueadas as chances de mobilizar seu capital de relações, as possibilidades de reconversão de Souza Carneiro ficaram quase que estritamente confinadas às atividades e aos eventuais dividendos extraídos de suas competências culturais e intelectuais. E a elas Souza Carneiro se lançou de maneira notável, passando a exercer suas habilidades polivalentes nas mais variadas e inusitadas áreas, transformando-se numa espécie de livre-atirador de gêneros e temas. Como registrou um amigo de Édison Carneiro e frequentador da casa do professor, "em fins de 1934, de malas arrumadas para o Rio, o velho Carneiro desdobrava-se numa atividade intelectual espantosa. Escrevia que nem um danado: um livro por semana" ${ }^{26}$. De tal monta que

${ }^{26}$ Biblioteca Nacional, Seção de Manuscritos, Arquivo Arthur Ramos, Carta de Clóvis Amorim para Arthur Ramos, 9 out. 1937, I-35,21532A. 
o ecletismo e a produção desvairada de Souza Carneiro resvalariam, por vezes, no descrédito e nas acusações de oportunismo e falta de seriedade intelectual.

O próprio Édison Carneiro, com uma lucidez doída, reconheceu a "profunda subversão" que as reviravoltas da política baiana produziram na vida do pai. Reviravoltas que "não somente lhe roubaram o estímulo como [também] lhe estragaram a saúde". A seu ver: "certamente isso explica que tivesse escrito" livros que "carecem, de certo modo, da estrita seriedade científica dos primeiros anos", e trabalhos "sem base na realidade" (Carneiro, 1943, pp. 319-320) ${ }^{27}$. De meados da década de 1920 em diante, o que se observa é a crescente dedicação de Souza Carneiro à literatura de ficção, à atuação na imprensa, ao ensaísmo político e etnográfico, aos domínios da geometria contemplativa e aos temas da maçonaria, do espiritismo, das ciências esotéricas e das forças ocultas atuantes na natureza e no homem, a exem104 plo da biografia Jesus!: mistérios das iniciações de Jesus de Nazareth (1927), fruto de sua filiação ao "seio fecundo e benfazejo do Círculo Esotérico" (Souza Carneiro, 1927, p. $4)^{28}$. No mesmo ano em que, como membro de alta gra-

27 Talvez, com isso, o filho estivesse respeitosamente dizendo que, ao final da vida, não apenas a saúde física do pai foi se deteriorando, mas também sua saúde e seu equilíbrio psicológico e mental. Na mesma carta acima mencionada de Clóvis Amorim para Arthur Ramos, o amigo de Édison (Clóvis Amorim provinha de uma família de senhores de engenho no Recôncavo) pintaria o retrato de Souza Carneiro marcado tanto pelo desgaste físico quanto pela sua "imaginação" por demais prodigiosa e "inventiva": "Furundungo [romance de Souza Carneiro, publicado em 1934] era a 'obra supimpa', como ele dizia, arrebitando o bigode crespo e mostrando o resto de dentes num sorriso vitorioso. Trazia um elucidário e, nele, oitocentos termos da gíria [popular do Recôncavo baiano]. Escrevia o romance e inventava os oitocentos termos. Visitando-o sempre, ele me ia lendo o romance, ao tempo em que decifrava o elucidário. Cada termo novo era um achado. E o romancista sorria [...] - Amorim, veja este. Conhece-o? [...] Não [...] Mas o termo estava fresquinho ainda. A imaginação de Souza Carneiro, havia poucos minutos, o tinha abortado". Biblioteca Nacional, Seção de Manuscritos, Arquivo Arthur Ramos, Carta de Clóvis Amorim para Arthur Ramos, 9 out. 1937, I-35,21532A; grifos nossos.

${ }_{28}$ Ainda, no livro Jesus!, há a informação de que o professor era o "Delegado Geral da Ordem do Estado da Bahia". A condição de maçom foi informada por seus pa- 
duação, foi um dos responsáveis pela fundação da Grande Loja Maçônica da Bahia, em Salvador, passando a figurar no segundo posto da hierarquia da nova loja ${ }^{29}$. Todo esse universo carregado de misticismo e esoterismo fazia com que, segundo Jorge Amado, Souza Carneiro assumisse as feições de "um mago":

Era um mago, vivia cercado por forças celestes e creio que adivinhava. Exercia poder absoluto sobre todos os centros espíritas de Salvador, especialista em Allan Kardec e em outros mestres da mediunidade [...]. Um mago, sem dúvida, sonhando com o futuro, incapaz de qualquer mesquinhez, tão desligado das misérias, da maldade e da feiura que fazia difícil distinguir no velho Souza Carneiro a fronteira que separa a realidade da imaginação. Nós o adorávamos, tínhamos nele não apenas um mestre, também um companheiro (Amado, 1981; grifos nossos).

De fato, seria difícil não se sentir de algum modo tocado pelos lampejos de tragédia que brotam desses retratos dos anos finais da vida de Souza Carneiro. Um personagem que surge revestido de certa nobreza quixotesca e que parece ter se sentido cada vez mais "desligado" da realidade de frustrações e "misérias", passando a se encastelar em um mundo de "sonhos com o futuro", cercado por "forças celestes", as quais, quem sabe, ele acreditava poder invocar a fim de intervir na série de transformações que foram gradualmente solapando tudo aquilo que estava na base de sua existência social, de sua autoestima e de sua identidade e

rentes, segundo os quais, inclusive, Souza Carneiro teria alcançado as graduações máximas na hierarquia (Carneiro, 2008). Em 1926, pela mesma editora paulista que lançou Jesus, Souza Carneiro também publicaria um livro chamado Ciência esotérica: análises e confrontos.

${ }^{29}$ A ata de fundação de Grande Loja da Bahia, que ainda existe, pode ser consultada no próprio site da instituição, no texto "Fundação da Grande Loja Maçônica do Estado da Bahia - 1927” (Sem autor, s.d.). 
orgulho pessoais. É possível imaginar, nesse sentido, o profundo impacto deste ambiente familiar na sensibilidade do jovem Édison Carneiro, desenvolvida precocemente e endereçada não apenas aos exercícios e às divagações intelectuais e literárias, como também à socialização com uma profusão insólita de práticas, repertórios e símbolos místicos e rituais que, certamente, contribuíram na produção de disposições intelectuais e afetivas necessárias para uma apreensão relativizada dos candomblés e das crenças de matrizes africanas. De outra forma, a convivência próxima e continuada com diversas formas de se relacionar com o plano místico e extrassensível que não apenas aquela professada pela fé católica dominante na Bahia possibilitou a Édison Carneiro não tomá-la como única ou absoluta ${ }^{30}$. Muito pelo contrário, como atesta um amigo (ainda que certamente com exagero), há razões para crer que, durante parte da juventude, o próprio Édison Carneiro se julgou capaz de manipular as 106 forças mágicas e celestiais conclamadas pelo pai:

Edison era um mestiçozinho de quase quinze anos, muito feio e muito tímido, que se dizia esoterista, meio mágico e meio adivinho, mas que não passava de um menino crente em bruxedos e doente de superstição. Não fosse ele filho de Souza Carneiro, esse doido de cabelos brancos, adepto da "goetia", que, num pardieiro da Rua São Bento, organizava uma espécie de "sabbat", evocando demônios maléficos, conjurando espíritos, entre o ritual sinistro das beladonas e

\footnotetext{
${ }^{30}$ Para essa frouxa socialização com o universo católico, muito pode ter contribuído a morte precoce da mãe. Édison Carneiro vivenciaria o catolicismo como algo distanciado, cujos contatos se davam unicamente pelo lado de sua tia paterna, Adília Rosa, celibatária e professora primária, cuja casa era bastante frequentada pelos sobrinhos. "A minha tia era bem religiosa: ia pra igreja, a gente que morava lá, ia todo domingo tinha que ir pra missa [sic]. Depois que eu fui crescendo mais, eu pegava meus irmãos, a gente dizia que ia pra missa e ia pra rádio [...] tinha a rádio sociedade da Bahia e de manhã eles faziam um programa e a gente ia [...] pra Rádio, e voltava pra casa, e dizia que tinha ido pra igreja” (Carneiro, 2008).
} 
dos meimendros. Edison vivia a escrevinhar tolices [...], era de uma fecundidade admirável. Aquele literatinho parecia que escrevia com as mãos e com os pés. Mal se adivinhava no Édison Carneiro de 1929 o escritor de $1937^{31}$.

No entanto, independentemente de quais fossem os destinos, as controvérsias, os temas e as atividades desenvolvidas em sua vida pública e intelectual ou privada, o importante a ser destacado é que Antônio Joaquim de Souza Carneiro conseguiu ser visto como um "nome que dispensa[va] apresentações", seja pelo seu "talento polimorfo", seja pelos "diferentes trabalhos de sua lavra"32, reconhecido e apontado como "uma das inteligências mais fulgurantes e cultas do nosso meio intelectual"33. Munido pela segura confiança de si e pela "polimorfia" de suas competências e da erudição adquirida no decorrer de sua vida profissional, Souza Carneiro parecia não duvidar das possibilidades de se sobressair em áreas como a literatura de ficção e os estudos etnográficos: investimentos que, em muito traziam os esforços do velho professor em reagir à situação incontornável de desgraça social, acadêmica, intelectual e financeira que se seguiu ao movimento de outubro ${ }^{34}$.

Mas, igualmente, não seria exagerado afirmar que a falência social e a percepção cada vez mais aguda da irreversibilidade da situação política baiana ajudam a enten-

\footnotetext{
${ }^{31}$ BPEBa. Clóvis Amorim, "Doidos”. Estado da Bahia, 15 jun. 1937.

${ }^{32}$ Fundação Clemente Mariani, Centro de Documentação e Informação Cultural sobre a Bahia (Cedic-BA). "A atualidade brasileira", Etc. n. 170, 16 ago., p. 1.

${ }^{33}$ BPEBa. "Nota sobre Comunismo, nacionalismo e idealismo". Diário da Bahia, 7 out. 1931.

${ }^{34} \mathrm{Na}$ ficção, conseguiria lançar dois dos seus romances: Furundungo e Meu menino, ambos publicados em 1934, no Rio de Janeiro, tendo como mote os costumes e a linguagem popular baiana e nos quais, "em discordância com o padrão da época, personagens negros surgiam como principais” (Oliveira, 1987, p. 25). Tais temas prendiam a imaginação de Souza Carneiro e, de alguma forma, reapareceriam em seus ensaios etnográficos, a exemplo de Mitos africanos no Brasil (1937) e em tantos outros manuscritos que, segundo Edison, ele teria deixado sobre a língua tupi e as mitologias das sociedades indígenas brasileiras (Carneiro, 1943, p. 320).
} 
der, ao menos em parte, o que pareceu ser o despertar de Souza Carneiro aos radicalismos ideológicos e à presença do proletariado na cena política brasileira ${ }^{35}$. Esse aspecto seria explorado em seu livro Comunismo, nacionalismo, idealismo, de 1931, que foi produzido justamente num momento no qual seu desespero era um sentimento crescente, ao assistir às forças varguistas tornando cada vez mais remotas as chances do "chefe" J. J. Seabra em retomar o poder no estado. Para tanto, não hesitaria em clamar pela radicalização do "nacionalismo revolucionário" e conclamar as classes proletárias a assumir seu papel nos destino da nação:

a revolução não se fez somente para depor um governo e logo montar outro com os mesmos cancros [...] Ela está preparando a Nação para a conquista de uma nova orientação em que predomine a política do trabalho [...] Nenhuma revolução vence sem que [...] triunfe 108 o proletariado ${ }^{36}$.

Enfim, a convocação do professor Souza Carneiro à radicalização das lutas políticas e ideológicas frente a qual Édison

35 Não deixa de ser interessante notar que foi na entronização de imagens do "operário" que Souza Carneiro encontrou um paralelo simbólico para dar conta de suas práticas espiritualistas e esotéricas. Práticas que não apenas buscavam valores exemplares na sabedoria dos "pobres" e dos "humildes operários", como também se pautavam nas "bases dos ensinos sublimes da benemérita Ordem [do Círculo Esotérico] de que somos humildes operários" (Souza Carneiro, 1927, p. 10; grifos nossos).

${ }_{36}$ BPEBa. "Em vez de nacionalismo, civilismo". Diário da Bahia, 29 ago. 1931, p. 2. O trecho constitui parte de uma palestra proferida por Souza Carneiro na Escola Politécnica. A palestra, que marcava o lançamento do livro Comunismo, nacionalismo, idealismo, era apenas uma, de várias, que Souza Carneiro vinha realizando na Escola Politécnica, na qual buscava se colocar como uma liderança política, incitando a "mocidade acadêmica" a tomar "parte na campanha pró-constituinte". O próprio livro já era o resultado de uma destas palestras: de uma "lição inaugural, proferida em abril de 1931, por ocasião da abertura dos cursos acadêmicos da nossa Escola Politécnica"; destinada a "todos os espíritos verdadeiramente empenhados na regeneração nacional”. BPEBa. "Comunismo, nacionalismo e idealismo". Diário da Bahia, 8 mar. 1932, p. 2. 
Carneiro dificilmente ficaria imune ou insensível: ainda mais quando se tratava de lutar contra um regime que, aos seus olhos, se confundia tão sensivelmente com a própria desestabilização de seu mundo familiar e com o progressivo debilitamento da saúde e dos sentidos de viver do pai.

\section{$* * *$}

A despeito das instabilidades que assombraram sua vida, o fato de Antônio Joaquim de Souza Carneiro ocupar uma posição prestigiada como catedrático da Escola Politécnica, receber nomeações diversas, acumular prêmios e obras que atestavam suas capacidades acadêmicas e culturais, e garantir - mesmo que a duras penas - o encaminhamento dos filhos às instituições nas quais as elites baianas formavam seus quadros, logrou minimizar os efeitos esterilizantes que a "raça" poderia ter na concretização de suas aspirações sociais e profissionais, assim como na de seus filhos. De modo que, diante de suas qualidades como homem culto, professor universitário, com trânsito e boas relações com chefes políticos locais, não chega a surpreender o fato de sua certidão de óbito atestá-lo como "branco":

Aos dez dias do mês de Dezembro do ano de mil novecentos e quarenta e dois, nesta Capital do Estado da Bahia [...] em meu cartório compareceu Mário Guimarães e exibindo atestado do Doutor Renato Lobo, declarou: que hoje às quatro horas e trinta e cinco minutos [...] na casa oitenta e sete à Rua Sodré, faleceu por colapso cárdio-muscular no curso de obstrução intestinal crônica Antônio Joaquim de Souza Carneiro, do sexo masculino de cor branca, de profissão Engenheiro, de naturalidade Bahia ${ }^{37}$.

37 APEBa, Seção Judiciária, Série Inventários e Testamentos, Antônio Joaquim de Souza Carneiro, ano 1943, Documento 05/2300/2800/06; grifos nossos. 
Mas é preciso ter cuidado na interpretação dessa branquitude atribuída ao insigne professor: ou melhor, nas formas de se compreender o "poder mágico" dessas "cartas de branquitude" que foram, nos termos de Gilberto Freyre, a "farda" e o "diploma" universitário no movimento de ascensão social do mulato no Brasil novecentista (Freyre, [1936] 2003, p. 727). Em grande medida, a trajetória de Souza Carneiro se mostra um caso eloquente das considerações feitas por Oracy Nogueira, quando afirma que a identificação ou classificação de um indivíduo quanto à cor constitui um complexo mecanismo de significação social, relativamente "maleável" e "flexível", capaz de se modificar conforme a "associação com outras características de status, como grau de instrução, a ocupação e hábitos pessoais, com tendência a se atenuar a cor de indivíduos socialmente bem-sucedidos" (Nogueira, 1978, p. 147). Evidentemente, isso não significa que a "raça" e a "cor" de Souza Carneiro foram 110 invisíveis aos olhos de seus contemporâneos. No entanto, a certidão de óbito, quem sabe, redigida por alguém próximo ou por algum admirador de seus talentos, ao classificá-lo como "branco", estava dando feição e expressividade mais a esses sinais "característicos de status" do que propriamente à "raça” ou à cor física. De qualquer forma, um fenômeno que, ainda segundo Oracy Nogueira, traz "embutido ou implícito o característico preconceito brasileiro, com o continuum de valorização da cor da pele humana, da branca e preta" (1992, p. 243) ${ }^{38}$.

\footnotetext{
${ }^{38}$ Ao tratar da trajetória do médico Alfredo Casemiro da Rocha, Oracy Nogueira evidenciou fenômeno semelhante ao de Souza Carneiro, quando se deparou com classificações conflitantes quanto à cor de Alfredo. Na certidão de casamento, ele aparecia como "preto", enquanto na de óbito constava como "pardo". Ambos os documentos foram lavrados na mesma cidade e em períodos não muito distantes um do outro: em Cunha (SP), entre as três primeiras décadas do século XX. Diz Nogueira: "Comentando a discrepância com um serventuário aposentado que conheceu os colegas responsáveis pelos dois termos, o mesmo explicou que o serventuário do casamento antipatizava com Alfredo, pelo o que o identificou como de cor preta, enquanto que o outro, por condescendência, lhe atenuou a cor" (1992, p. 243).
} 
Com os dados e materiais disponíveis, seria impossível extrair elementos mais substantivos quanto aos modos pelos quais o professor da Politécnica se autorrepresentou no que diz respeito aos componentes étnicos de sua identidade. $\mathrm{O}$ mesmo pode ser dito com relação às eventuais e prováveis situações de preconceito racial por ele sofridas, percebidas ou não enquanto tais. Contudo, parece verossímil afirmar que Souza Carneiro e sua família dificilmente foram vistos como negros numa sociedade como a baiana. Nas primeiras décadas do século XX, tal categoria buscava instituir simbolicamente dois grupos de pertencimento que, muitas vezes, mas nem sempre, coincidiam: os sujeitos considerados portadores ou praticantes de uma "cultura africana”, com todas as propriedades reificantes a ela associada (barbárie, degeneração moral e sexual, violência etc.), e aqueles alocados na base da hierarquia social, "especialmente os que vivem do trabalho manual e braçal" (Azevedo, 1966 , p. 36) ${ }^{39}$. O ponto é importante, pois retém dois elementos que, pela recusa e pelo contraste, funcionavam como sinais de distinção indispensáveis para entendermos a forma como Édison Carneiro, notadamente nas primeiras poesias de juventude, objetivou sua posição na estrutura "racial" e de classe de Salvador. Tal posição a antropóloga norte-americana Ruth Landes (1908-1991) observou de maneira exemplar, ao relembrar de sua surpresa quanto ao fato de a "raça" de Edison nunca haver sido mencionada nas cartas de apresentação dadas a ela, na ocasião de sua chegada à Bahia, em 1938:

Pareceu-me significativo que Edison fosse um mulato, da cor trigueira chamada parda no Brasil. Era significativo porque

\footnotetext{
39 Sobre a estratificação e os esquemas de percepção racial em Salvador analisados em diferentes momentos históricos, ver o clássico trabalho de Donald Pierson ([1942] 1971); além de Azevedo ([1953] 1996), Landes ([1947] 2002), Bacelar (2001), Sansone (2003) e Figueiredo (2002).
} 
as cartas de apresentação vinham de colegas brancos, que não haviam mencionado a sua raça ou cor. Para eles isso não importava. Aceitavam-no pelo seu provado valor como jornalista e como erudito. Em nenhum momento percebi de sua parte, qualquer preocupação especial com minha raça [Ruth Landes fazia referência à sua origem judaica]. [Ele] vinha de família pobre mas boa, qualificada de fidalga. $\mathrm{O}$ pai, de tez clara, era professor de engenharia aposentado, de ótima reputação por trabalhos originais. A tia parecia índia e era diretora de uma escola. Um dos tios era juiz. Um irmão mais velho era advogado conhecido [...] Era o tipo de família às vezes chamada de "negros brancos", por muito respeitada (Landes, [1947] 2002, pp. 49-50; grifos nossos).

\section{Raça, classe e cor nas poesias de juventude}

A leitura das primeiras poesias de juventude de Édison Carneiro constitui uma porta de entrada interessante para

112 observarmos como esta inscrição "fidalga", nas palavras de Ruth Landes, rebate no registro de uma sensibilidade com forte senso de colocação social, mas abalado, às vezes, pelas incertezas e penúrias vivenciadas pela família naquele momento. A produção poética corresponde a um curto período de sua vida, confinado aos anos de 1928-29, quando o autor tinha apenas 16 e 17 anos. Na época, Edison finalizava os estudos básicos no Ginásio da Bahia e, provavelmente, começava a se preparar, seguindo os mesmos passos dos dois irmãos mais velhos, Franklin e Nelson, para o ingresso na Faculdade de Direito; o que, de fato, veio a ocorrer em 1930. Tratava-se de um momento de sua vida em que talvez começasse a sentir os primeiros prenúncios de uma vocação para "homem de letras" ou jornalista, embalada não apenas pela força dos exemplos do pai e dos irmãos, mas também pelas fantasias que deviam revestir a vida de um jovem às vésperas de ingressar numa faculdade em que "repontavam, ali, vocações promissoras para as letras, a política, o jorna- 
lismo, a advocacia, a magistratura e a cátedra universitária” (Nogueira, 1978, p. 16).

Pode-se dizer, nesse sentido, que as experiências de Édison Carneiro como poeta iniciante deram vazão a essa ebulição de fantasias juvenis, em muito marcada pelas tensões de seu ambiente familiar - àquela altura amargando o ostracismo da facção política do pai -, bem como pela sua condição de quarto filho homem, "muito feio e muito tímido" 40 . E liberto, em parte, das pressões de destinação social e profissional que recaíam sobre os mais velhos; sobretudo em torno de Nelson, que "era outra coisa, alto, bonitão e [...] bom orador" (Carneiro, 2008), desde muito cedo encaminhado pelo pai e pelo tio paterno, José Joaquim, ao convívio próximo com Seabra (Carneiro, 1990). Afinal, como chamou a atenção Sergio Miceli, seria importante não minimizar os efeitos decisivos da "falência" material, da política familiar e da posição de seus membros na linhagem, relegando os caçulas ou os mais novos dessas "famílias de "primos pobres' da oligarquia" aos trabalhos menos "masculinos" ou prestigiados: "tais situações de relegação punham fora de seu alcance [dos caçulas] os investimentos com que são brindados os primogênitos e os ocupantes das demais posições privilegiadas no espaço da fratria e da linhagem" (2001, p. 162). De modo que Édison Carneiro não esteve ileso às expectativas e aos investimentos diferenciados que a família depositava em cada um de seus membros, conforme suas posições na linhagem.

Ainda estudante ginasial, Édison Carneiro assistia à agitação familiar em torno das disputas políticas baianas; família que, graças à Aliança Liberal, encontraria a oportunidade esperada, desde 1924, de ver seu "chefe" novamente vencedor. J. J. Seabra retornou a Salvador para encabeçar a cam-

${ }^{40}$ BPEBa. Clóvis Amorim. "Doidos". Estado da Bahia, 15 jun. 1937. "Era o mais feinho de todos. Era feio que o coitadinho... Quando era adolescente, depois ficou mais velho, engordou mais, ficou melhor" (Carneiro, 2008). 
panha aliancista, encontrando forte apoio, principalmente, nos grupos de jovens universitários (Sampaio, 1998). Entre esses universitários já se destacava por sua liderança estudantil, na Faculdade de Direito, o irmão de Edison, Nelson Carneiro, sobre o qual recaíram as chances de fazer valer as "lealdades" da família em favor de uma carreira política. Embora não fosse insensível ao momento, Edison contava com um ambiente de relativa despreocupação e liberdade para o exercício das divagações e "inquietações" do espírito, podendo contar com a "sala cheia de estante de livros" (Carneiro, 2008) do pai e com a presença dos amigos de ginásio e da Academia dos Rebeldes que começavam a frequentar a casa de Souza Carneiro - para onde, sem dúvida, todos esses "incipientes literatos" afluíam - na certeza de ali gozarem de toda sorte de estímulos e licenças possíveis às "bagunças" barulhentas e aos debates acalorados.

114 Senhor de imaginação e magia, um mestre da vida [...] Em sua residência nos Barris, alcunhada de Brasil - por enorme, desorganizada e entregue às baratas - nos abrigamos os rebeldes [...] Seu filho, Edison [...] figurava entre os mais combativos da novel agremiação e o outro filho, o mais velho, Nelson, com ela simpatizava, se bem olhasse com certa reserva e alguma suspeita aquela agitação de incipientes literatos: já então o futuro senador Nelson Carneiro participava da vida política, líder estudantil de notória atuação. O professor Souza Carneiro não nos olhava com suspeita nem com reservas; ao contrário, dava-nos caloroso apoio, compartia de nossas inquietações, sustentava nossa batalha, em sua casa dos Barris, pobre e misteriosa. O professor, segundo afirmava, escondia no quintal um avião [...] que lhe serviria para controlar do alto dos céus as próximas eleições às quais pretendia concorrer, candidato a deputado pela oposição (Amado, 1985; grifos nossos). 
Desse modo, algumas das chaves de leitura que conferem sentido aos poemas de Édison Carneiro encontram-se nessa longa citação de Jorge Amado. Significativamente, os primeiros deles saíram, entre os meses de setembro e novembro de 1928, no jornal A Noite, órgão aparentemente simpático aos interesses dos democratas baianos e de seu cacique J. J. Seabra ${ }^{41}$. Em sua maioria, trata-se de poemas cujos temas não fogem muito a alguns clichês da época, próprios a um jovem que começava a arriscar seus primeiros versos: recortes da paisagem local, frustrações amorosas, visões de mulheres ideais, flertes e inseguranças afetivas e mesmo taras sexuais. Contudo, em meio aos transes amorosos, Édison Carneiro não deixa de registrar as fortes incertezas que pontuavam suas fantasias de projeção social e intelectual, imprimindo um desânimo ou "ceticismo" à realidade que, por vezes, quebra o clima de "alegre farra" do conjunto dos poemas.

Talvez, do ponto de vista formal, certo ar de novidade ficasse por conta da frouxidão rítmica e do uso dos versos livres, de feitio humorístico e irônico a valores e sensibilidades românticas, que contrastava com a gravidade dos sonetos e dos poemas elevados que abundavam os jornais e as revistas literárias de Salvador. Em alguma medida, evidencia-se que a leitura e apreensão das linguagens literárias modernas começavam a surtir efeito entre os intelectuais locais $^{42}$. O expediente irônico aos valores românticos é

\footnotetext{
${ }^{41}$ Embora não tenha maiores conhecimentos sobre o jornal A Noite, nele também colaboravam jornalistas de reconhecidas ligações com Seabra, a exemplo de Cosme de Farias (1875-1972): "Em grande parte da vida política de Cosme de Farias, sua principal aliança era com os seabristas. Segundo Mônica Celestino, 'Cosme seguia a decisão do ex-governador José Joaquim Seabra [...] e do seu grupo de não apoiar os jovens Calmons, Otávio Mangabeira e Simões Filho'” (apud Oliveira, 2004, p. 108).

42 "O modernismo de 1922, que se firmava e se diversificava, foi transportado de São Paulo até aqui [Salvador] somente em 1927, cinco anos mais tarde, quando apareceram os poemas de Eugênio Gomes, Moema e A balada do ouro, de Godofredo Filho, grande poeta baiano [...] E foi aí que os grupos literários começaram a surgir" (Amado apud Raillard, 1992, p. 34).
} 
mais nítido, por exemplo, no poema "O que falta a uns", no qual o poeta concebe tais valores como uma absoluta "tolice", mas que não pode ignorar ou abandonar sob pena de perder suas amantes:

Eu, de namoradas, / tenho três... / E, a cada uma / digo / uma tolice... / São três mulheres / de quem eu / ocupo o tempo / enchendo-lhes os ouvidos / de pulhices românticas / e de juras dum amor / que eu nunca senti (Carneiro in Santos, [12/10/1928] 2005, p. 75) ${ }^{43}$.

Vale chamar a atenção para um elemento importante na leitura dos poemas que Édison Carneiro publicou em 1928, no jornal A Noite. O autor os concebeu nos moldes de um "folhetim poético" (Seixas, 2005), formando uma série única e coerente de poesias intitulada de "Musa capenga"44. Assim, a maioria das poesias foi publicada com poucos dias 116 de distância umas das outras, quando não nenhum. Ao que parece, a intenção era de que fossem lidas de modo articulado. Desse modo, parece significativo que logo no primeiro poema da série, "Primavera", Carneiro lançasse mão de certas coordenadas sociais quanto ao lugar ou a posição

\footnotetext{
${ }^{43}$ Salvo indicação contrária, todas as poesias de Édison Carneiro citadas encontram-se reunidas no livro de Gilfrancisco Santos, Musa capenga. Assim, após as citações serão mencionadas apenas a data original da publicação e a numeração da página em que o poema se encontra. Alguns dos poemas estão sem dia e mês especificados. Nestes casos será colocada apenas a página. Todos os poemas não fogem ao período já mencionado: de setembro a novembro de 1928.

${ }^{44}$ Não saberia precisar as razões ou os sentidos implicados no título "Musa capenga", dado ao conjunto dos poemas. A única pista que encontrei (ainda assim bastante frágil) poderia indicar se tratar de uma tirada de humor com relação a uma seção diária de poesias que existira em Salvador, por volta de 1922, e que se chamava "Musa baiana". Conforme a autobiografia do magistrado baiano Adalício Coelho Nogueira (1902-1990), tratava-se de uma seção de poesias empreendida em prol da candidatura à presidência de Arthur Bernardes, podendo daí aventar a hipótese de se tratar de poemas de exaltação à Salvador, à Bahia e ao Brasil: exaltação à Bahia que Édison Carneiro, talvez, ironizasse com a sua "Musa capenga" (Nogueira, 1978, p. 23).
} 
a partir da qual a realidade estava sendo apreendida. Os elementos mais significativos que conferem uma identidade social própria ao poeta eram, sobretudo, aqueles que o circunscreviam como um "estudante". Tal critério de localização é decisivo para se entender os tipos de experiências, espaços, relações e sentimentos que se encontram invocados no conjunto dos poemas.

Os estudantes / em alegre farra / passaram cantando / [...] brincando fingindo / uma gargalhada / que é / um manto enorme / que cobre / o enfezamento / desta vida tão má... / eu também brinquei, / eu que, também / sou estudante / [...] Estavas lindas Cremilda / Se não fosse / a grande distância / que me separava / do teu carro / eu teria / dado um pulo / e festejando / a primavera / beijando-te na boca ([24/09/1928] 2005, p. 67).

O "estudante", portanto, funciona como uma informação projetiva que recobre todos os poemas seguintes, construídos em torno de aventuras, frustrações e episódios que se imaginam próprios a tal condição. E ainda, reivindicando para si o direito de compartilhar as "alegrias", farras e paqueras nas ruas da cidade, o poeta parece se utilizar da condição estudantil como uma estratégia de evasão às mazelas da vida. Nesse sentido, o primeiro poema prenuncia uma tensão que será constante no restante da série: aquela entre as "alegrias" e as farras amorosas de um estudante, ainda livre de certos compromissos sociais, e as incertezas e as dúvidas quanto aos destinos de um jovem aspirante a intelectual e escritor, frente a um ambiente percebido como hostil. "Ostracismo intelectual", por exemplo, desnuda por inteiro as apreensões e as amarguras do literato iniciante, potencializadas ainda mais pela percepção da distância que separa o intelectual de província dos grandes centros de consagração e produção cultural do país: "Seu mano, / 
estou com vontade / de escrever uma novela... / Mas como não quero / que a crítica me rache / com a cartola / [...] $\mathrm{Na}$ Bahia, os talentos / vivem e morrem esquecidíssimos / dos outros intelectuais / [...] É verdade... / quanto mais / o pobre do meu eu!" ([s.d.] 2005, p. 82).

Édison Carneiro transpõe para o plano ficcional um registro sintético das ambiguidades vivenciadas no plano familiar, em suas possibilidades concretas de rebaixamento social: ao receio do ostracismo intelectual, sobrepõe-se perfeitamente o dramático ostracismo político da facção política do pai. Essa situação, mesmo aos olhos de um ginasial muito moço, já se pronunciava traumática o suficiente, a ponto de produzir fissuras na própria experiência do tempo, como é possível observar em "Ontem e hoje". Nesse poema, os versos foram arranjados na chave de um jogo de contrastes secos entre um passado de "bonança", porém fantasioso e "irreal", e um presente doloroso e "triste" da "vida verda118 deira" imersa em "tempestades" e sonhos renunciados ${ }^{45}$ :

Ontem e hoje, / alegria e tristeza / amor e esquecimento / vida irreal e vida verdadeira / vida ilusória e vida na própria vida / castelo de ilusões e realidade esmagadora /

\footnotetext{
${ }^{45}$ A percepção de um ambiente social hostil também está presente num outro poema, intitulado "Idiotas...". Os versos afirmam o ceticismo do autor perante as coisas: "O ceticismo / é coisa boa / Muito boa mesmo [...] Por isso eu / que tenho cá minhas ideias / já deixei / de acreditar / em todas as pulhices / que andam por aí... / E esses trouxas / que não raciocinam [...] dizem: / - Coitado! / Além de pobre / acético e materialista" ([17/10/1928] 2005, p. 78). Com relação às angústias do escritor em terras provincianas e passadistas, Édison Carneiro escreveu "A chuva e a Sé", em que lamenta a chuva não ter sido capaz de pôr abaixo a igreja da Sé, símbolo tanto do catolicismo quanto da arquitetura coloniais de Salvador: "A nossa pobre cidade, que do Salvador só tem o nome, passou, anteontem, Domingo, algumas horas de verdadeira fúria contra a chuva... / As ruas todas - um perfeito lago; aqui e ali chuva só; roupas encharcadas; os pés molhados a mais não poder [...] Eu gritei contra a chuva... Dei-lhe epítetos, disse-lhe... / palavradas infâmias, misérias... / Mas não fiz isso porque ela tivesse caído tão assustadoramente sobre a capital. Gritei com razão... Razão de sobra! / Gritei por ela não ter sido mais forte para derrubar a Sé!" ([13/11/1928] 2005, p. 95).
} 
bouquet de rosas e espinhos de outras rosas / mar de bonança e mar de tempestade / espectro já morto e entidade ainda viva / ilusões que morreram e espera nças que nasceram ([20/11/1928] 2005, p. 98).

Entretanto, um aspecto importante a ser ressaltado é que em nenhum momento os lamentos sobre a pobreza e as incertezas de reconhecimento que rondam a existência do poeta parecem desestabilizar o senso de colocação e a identidade social do autor. $\mathrm{O}$ raio de ação das poesias quase não foge dos lugares frequentados pelas elites: as ruas dos estudantes, onde passeiam os carros dos afortunados, e aonde acontecem os flertes e pedidos de beijos com as moças "que [dizem] ser do chic e do bom-tom" ([23/10/1928] 2005 , p. 84). Em apenas duas ocasiões aparecem elementos nitidamente estranhos e distantes ao universo social que o poeta vivencia: intrigantemente elas ocorrem nas duas vezes em que Édison Carneiro faz referências explícitas a elementos percebidos como "negros" naquele contexto. Uma estranheza e/ou distância que se estabelecem, ora pela tirada jocosa, ora pela invocação do místico ${ }^{46}$. No primeiro deles, "Ameaça", os versos servem como uma advertência do poeta à amante, ameaçando colocar uma "coisa feita" na porta da casa dela, caso ela não correspondesse ao seus sentimentos:

Meu anjinho / não me despreze / olhe, veja lá: / se você não me quiser... / eu não me mato não! / Mas vou / ao Pau Miúdo / e trago, / pra botar na sua porta / uma coisa feita / dessas que fazem / morrer de amor, / preparada /

\footnotetext{
${ }^{46}$ Sem dúvida, aqui pesava a influência do pai, levando Édison Carneiro a se interessar pelos temas místicos e religiosos, chegando mesmo a anotar em um de seus poemas que a "religião" era seu "tema predileto" ([17/10/1928] 2005, p. 78). No conjunto de suas poesias, em mais de uma ocasião Édison deixaria emergir esse seu interesse. Por exemplo, o poema "Horóscopo", em que dizia ser o "bicho / nas previsões... / E quando tenho qualquer medo / podem escrever / que aquilo / me acontecerá" ([08/11/1928] 2005, p. 92).
} 
minha beleza, / pelas mãos / do grande mago / Jubiabá! ([22/10/1928] 2005, p. 83).

Muito antes de Jorge Amado consagrar o nome desse pai de santo com seu romance Jubiabá, de 1935, o mago já gozava de amplo conhecimento da parte do público e das autoridades da sociedade soteropolitana e, pelo visto, com clientela endinheirada e importante. Contudo, não era de maneira positiva que o "famoso Jubiabá" aparecia nos noticiários, mas sim, pela charlatanice e "selvageria" de suas práticas, somente "explicáveis nos tempos coloniais" ${ }^{47}$. E, nesse sentido, embora não se valesse da categoria "negro" ou outra equivalente para qualificar a cor do "mago", Édison Carneiro mobilizava um nome (Jubiabá) e uma prática (coisa feita), certamente convencido de que, assim como ele, seus leitores os entenderiam como associados a "negros" e "africanos" 48 .

Ao mesmo tempo, existe uma forte distância separando o espaço que o poeta e a amante ocupam e aquele onde se encontra Jubiabá: esse está "lá” no Pau Miúdo, região periférica e pobre de Salvador. Entretanto, tal distância deve ser lida apenas como um marcador de outras, mais significativas, de natureza social e cultural. Afinal, são os ingre-

\footnotetext{
47 BPEBa. "Os despachos 'feiticeiros'”. A Noite, 26 mar. 1925, p. 2. Quatro dias antes, no mesmo jornal, noticiava-se o absurdo de "rapazes, velhas e mocinhas de boa aparência" frequentarem o "famoso Jubiabá", um tipo charlatão que vivia "catando os níqueis dos incautos". BPEBa. "Os domínios de Jubiabá". A Noite, 22 mar. 1925, p. 3. Vivaldo da Costa Lima também faz referência ao pai de santo Jubiabá que, ainda na metade da década de 1930, mantinha um terreiro prestigiado, frequentado inclusive por "políticos e autoridades policiais do Estado" (1987, p. 41).

${ }^{48}$ Interessante que a ameaça que Edison jogava através da "coisa feita" guarde os mesmo termos da "promessa" que ele fazia à pretendente a amante em um outro poema, sem título: nele, ao invés de ameaçar colocar uma "coisa feita”, o poeta prometia, caso a moça finalmente aceitasse a beijá-lo, não mais "visitar / a caboclinha / de lá da Sê" ([24/11/1928] 2005, p. 85; grifos nossos). No limite, o autor não deixava de fazer uma ameaça pois, caso contrário, fica-se subentendido que ele iria procurar a "caboclinha”. De alguma forma, Édison Carneiro sugere que a "caboclinha" estava em oposição social e racial à moça que ele queria conquistar.
} 
dientes místico, mágico e feiticeiro de Jubiabá que, em grande medida, controlam o significado social da categoria "negro" no poema, sem perder de vista seu sentido cultural de "africano" (conforme deixam entrever os noticiários dos jornais), talvez nítido o suficiente para não ser verbalizado e, mesmo assim, compreendido ${ }^{49}$. Portanto, a "racialidade" do poema - se assim é possível dizer - fica mais por conta da distância social e cultural do poeta do que pela eventual descrição positiva de uma pigmentação de pele.

Contrário ao último exemplo é o poema "Ralhando", no qual as características físicas de uma mulher negra servem de motivo para um humor depreciativo. Nele, mais uma vez flagra-se marcadores socialmente distintivos pontuando a narrativa, que garante, assim, uma margem segura de distância entre o poeta e a personagem em tela, uma "negra faceira" e sua "tolice" por ter: "espichado / o seu cabelo. / Para que / essa beleza / artificial”. Afinal, "de que lhe serve / andar assim / com ligas melenas / se todo mundo sabe / que negra / nunca teve / cabelo bom?" ([s.d.] 2005, p. 87). $\mathrm{E}$, na sequência, os versos elucidam as razões pelas quais se condena a atitude da mulher em alisar seus cabelos: "O governo / Federal, já se vê / projeta agora / Construção / de estradas de ferro / e de rodagem / E você / bem que podia / concorrer / com o pixaim / para cercá-las / a farpas de arame!” ([s.d.] 2005, pp. 87-88).

Ora, o poeta tenta tirar proveito irônico do ridículo atribuído ao fato de uma "mulher negra" alisar as "melenas”, imprimindo a si própria uma imagem "artificial”

\footnotetext{
${ }^{49}$ Como lembra Jeferson Bacelar, a categoria "negros" foi significada de múltiplas formas no contexto da sociedade baiana, acionada para justificar diferentes tipos de "problemas sociais": imoralidade, degeneração sexual, criminalidade, violência etc. Contudo, ele chama a atenção para o fato de que nenhum tema ganhava tanto destaque nos jornais baianos, nos primeiros decênios do século XX, quanto os candomblés, apreendidos fundamentalmente como entraves "culturais" e menos raciais, "entendidos como um espetáculo vergonhoso de atraso numa sociedade que pretendia civilizar-se” (1991, p. 50).
} 
que contrastava, afinal, com o que "todo mundo sabe", ou seja: com a "natureza" farpada de seu cabelo. A aspereza do cabelo pixaim faz par com a "rudeza" do espírito da mulher, cuja tolice maior, quem sabe, seria a de acreditar que uma "negra" pudesse dissimular os aspectos de sua aparência racial (se aproximar de uma beleza "branca" e, por isso, "artificial"?), ao modificar simplesmente seu físico. Ironicamente, a ironia parece ganhar eficácia cômica na justa medida em que mobiliza códigos semelhantes ao do poema sobre a "coisa feita". Dito de outra maneira, os elementos deflagradores do cômico e do riso no poema, aos olhos de Édison Carneiro, bem como aos de seus leitores da elite baiana, não estariam nessa tentativa infrutífera e vexatória da mulher em negar sua "natureza" racial, alterando a aparência física? E, portanto, na ingenuidade "tola" de tentar burlar sua raça sem estar de posse de certas faculdades sociais e culturalmente distintivas para que 122 assim procedesse ${ }^{50}$ ?

Em suas poesias - e em particular à luz das duas últimas apresentadas -, Édison Carneiro objetivava a si próprio na vida social baiana a partir do lugar de um "não negro", cuja fala é flagrantemente pontuada por marcadores que asseguravam distâncias entre o seu mundo e aquele dos "negros" por ele retratado. Uma fala socialmente possível

\footnotetext{
${ }^{50}$ Tomo emprestado, aqui, uma reflexão de Heloisa Pontes, quando, realizando uma história social do teatro brasileiro, desvela as várias possibilidades das atrizes em "burlar", nos palcos, uma série de constrangimentos impostos pelo "tempo" e pela natureza imaginária das relações de gênero. Ou seja, o teatro, como um espaço de negociações de sentidos e convenções sociais e culturais, permite colocar em suspenso certas propriedades corporais que, em outros contextos, seriam facilmente percebidos e marcados. Como o fato, por exemplo, de uma mulher representar, nos palcos, um homem ou personagens com idades distintas da atriz (Pontes, 2004; e, em especial, 2010).
} 
por estar lastreada em esquemas de classificação homólogos àqueles que resultaram na branquitude certificada do pai, Souza Carneiro, na ocasião de sua morte. E aqui, tanto pai quanto filho nos colocam em face dos dilemas implicados nessas classificações que informaram a existência e a trajetória social dos Souza Carneiro. Trata-se de algo que, trocando em miúdos, podemos traduzir nos termos dos próprios desafios envolvidos na compreensão das formas como Édison Carneiro operacionalizou a "raça" como um mediador simbólico de suas experiências sociais e familiares, bem como nas percepções de si e de suas posições na sociedade baiana.

O que nos revelam, então, a "morte branca" de Souza Carneiro e a "poesia não negra" de Edison? Antes de qualquer coisa, o modo como os Souza Carneiro não se viam e não foram vistos (pelo menos, na maior parte do tempo e das circunstâncias naquele contexto), ou seja, como negros. Nesse sentido, é importante não minimizar toda sorte de distinções que se estava em condições de, subjetiva e objetivamente, vivenciar a partir desse contraste, percebido negativamente e irredutível a supostas afinidades, identidades ou condições de raça que antecedem o uso que as pessoas e os grupos fazem delas em contextos e momentos específicos.

Como procurei mostrar neste artigo, em enorme medida, a posição dos Souza Carneiro no sistema de representações de raça e status foi possível graças ao sucesso dessa família de mestiços baianos em dispor, em variáveis proporções, de meios sociais, econômicos e culturais, investidos por indubitáveis sinais de diferenciação com os negros baianos: educação formal, diplomas, profissões prestigiadas, capital de relações etc. Enfim, há em jogo uma série de elementos que mediavam suas existências em face das etiquetas de tratamento racialmente dispostas pela sociedade baiana, a qual criou sofisticados mecanismos de classificação a fim de dar conta, nos termos de Thales de Azevedo, 
da ascensão e presença de suas "elites de cor": mulato, mestiço, moreno, negro branco, negro da terra, pardo etc. (Azevedo, [1953] 1996).

Tal relação sensível entre hierarquia e códigos de comportamento e distinção, produtores de "qualidades" e "autoestimas", que em Salvador se expressava e se racionalizava racialmente, foi registrada de modo pioneiro e competente por Thales de Azevedo nos inúmeros exemplos que, na década de 1950, pôde observar e descrever entre seus informantes. Assim, "quando alguém se dirige a um preto de classe inferior pode, por exemplo, compará-lo a outro 'preto como você', mas tratando-se de pessoas de classe mais alta a etiqueta manda empregar o vocábulo escuro ou mesmo moreno" (Azevedo, [1953] 1996, p. 36); ou então, o caso de um pai indisposto com o termo "negro" registrado na ficha de atendimento de seu filho pelo médico que o atendera e junto ao qual foi protestar, alegando que prefe124 ria "escuro" ou "preto"; e mesmo o exemplo do "intelectual mulato escuro" que sabia que, quando queriam lhe ofender, "chamam-no 'aquele negro"” (Azevedo, [1953] 1996, p. 36). Nessas e nas muitas outras situações descritas por Azevedo, somente o olhar insensível à força de realidade que as representações impõem àqueles que as vivenciam poderia ignorar as diferenciações (apenas em aparência sutis), bem como as licenças ou os constrangimentos que categorias como "preto", "negro", "escuro" ou "moreno" operavam, em seus contextos de uso, conforme as intenções e as posições dos agentes.

Seja como for, o mais importante nessas considerações, parece, não é usar esses vocábulos em qualquer espécie de esforço de descobrir, afinal, a qual deles Édison Carneiro pertenceu ou esteve enquadrado, plastificando de antemão a trajetória social e intelectual de Édison Carneiro a partir de uma "identidade de raça primordial e inclusiva (i.e. excludente de outras identidades possíveis)" (Azevedo, 2004, p. 
$83)^{51}$. Até porque a racialidade de Edison seria o próprio móvel de tensões políticas e ideológicas em determinados momentos de sua vida, não sem consequências para se entender as lógicas de suas escolhas no campo intelectual. Trata-se, sobretudo, de chamar a atenção para a necessidade de não se descolar as formas como Édison Carneiro percebia a si próprio, bem como o mundo que vivenciava, do quadro mais nuançado e mediado por sua trajetória e experiências familiares. Tais experiências informaram modalidades particulares de representações em meio às quais ele foi aprendendo a ordenar simbolicamente suas posições na sociedade baiana. Nesse sentido, suas primeiras poesias e a morte branca do pai são objetivações eloquentes dessas representações, cujo silêncio quanto a uma negritude (auto) atribuída é revelador, menos de uma simples "fidelidade acrítica” (Spitzer, 2001, p. 143), emudecida e/ou subalterna à "classe dominante branca" (Lima, 2001; Guimarães, 2004a, 2004b), e muitos mais das possibilidades de Édison Carneiro e sua família em investir (e serem investidos) de qualidades e distinções que colocava a raça em suspensão, com o intuito justamente de minimizar o risco de terem suas identidades monopolizadas, atacadas ou preferencialmente invocadas nesse registro.

Para tanto, certamente, puderam contar Edison e os Souza Carneiro, assim como outras tantas pessoas e famílias que ajudaram a dar feição às elites mestiças baianas,

\footnotetext{
${ }^{51}$ Plastificar e essencializar uma trajetória em uma identidade racial primordial ou, o que dá no mesmo, quando aplicadas à história do pensamento social no Brasil, tratar os intelectuais de ascendência africana na chave enrijecida de uma "intelectualidade negra". Como se tudo que eles tivessem feito ou pensado tivesse uma indelével natureza racial: quando não, tratados como figuras um tanto arrivistas, cujos fins eram o de se "filiar" ou assimilar a uma sociedade e "ciência branca" dominantes. No que diz respeito a um trabalho expressivo deste tipo de abordagem e no qual o próprio Édison Carneiro aparece tangencialmente como "objeto", pode-se mencionar o artigo de Ari Lima (2001) sobre o "lugar do intelectual negro" no meio acadêmico brasileiro. Projeta-se Carneiro num ambiente asséptico, esterilizado de toda sorte de resíduos sociais, menos os raciais.
} 
além dos sinais de distinção que manipulavam, com um "nicho" propício para que eles fossem capazes de vivenciar esta negritude sem ser negro naquele contexto; ou uma negritude sem etnicidade, para falar nos termos de Lívio Sansone $(2003)^{52}$. Afinal, como assinala Antônio Sérgio Guimarães, não parece aleatório que movimentos de afirmação política em torno da "raça", de uma "consciência de raça", tenham florescido no Brasil com maior vigor, especialmente a partir das duas primeiras décadas do século XX, "em São Paulo, onde a imigração estrangeira foi mais importante" (2003a, p. 54). Ali, os esforços em prol da elevação moral "da raça" e da mobilização dos "homens de cor" ganharam corpo e se constituíram politicamente em torno da percepção comum de desalojamento e marginalização, enquanto "negros", dos empregos e serviços mais valorizados - oferecidos pela expansão e consolidação de uma sociedade industrial e competitiva -, sistematicamente ocupados pela presença 126 maciça da mão de obra imigrante branca de origem europeia desde finais do século XIX. Tal situação de "bloqueamento" aos empregos mais vantajosos e estáveis no mercado de trabalho urbano e industrial, articulada aos "incentivos" de "cunho moral" que provinham da "emulação indireta, provocada pelo êxito econômico e social dos imigrantes, especialmente dos italianos, simplificou enormemente", segundo Florestan Fernandes, "a escolha de objetivos comuns"

\footnotetext{
${ }_{52}$ Tem-se uma negritude sem etnicidade na medida em que, aponta acertadamente Sansone, a "identidade étnica pode ser [entendida como] relativamente independente da cultura étnica" na "construção de estratégias de sobrevivência e mobilidade social" (2003, p. 291). Em outras palavras, a identidade etnicamente invocada ou atribuída, mesmo que a contragosto das pessoas ou dos grupos assim classificados, não é necessariamente vivenciada na chave de um pertencimento a uma "cultura" ou "comunidade" étnica: ou seja, como etnicidade, como marcadores de "fronteiras" políticas suportadas pela manipulação de traços de ascendência ou origens comuns. Trata-se, portanto, recorrendo mais uma vez ao trabalho de Sansone, de "buscar" e "investigar" a "etnicização e a negritude onde estas podem ser encontradas, em vez de insistir em que elas devem estar em toda parte" (2003, p. 297). Sobre etnicidade, ver Barth (1998), Oliveira (1976), Cunha (1985, 1986) e Brubaker (2002).
} 
aos negros e mestiços paulistas, e acabou precipitando o surgimento de jornais, lideranças, movimentos, ideologias e formas de consciência política que buscaram se justificar a partir de vinculações e "impulsões inconformistas" especificamente raciais (Fernandes, 2008, pp. 15-16).

Não vem ao caso aqui estabelecer parâmetros mais sistemáticos de comparação entre as diferentes formas ou estratégias de integração da antiga mão de obra servil e não branca em face do colapso da escravidão e da consolidação do trabalho livre e assalariado (Fernandes, 2007, 2008; Bastide e Fernandes, 1958). Contudo, cabe destacar que a Bahia, diferentemente de São Paulo e mesmo do Rio de Janeiro, tanto pela ausência de contingentes mais expressivos de imigração europeia - capazes de ameaçar a inserção, desigual, porém contínua de seu contingente não branco a postos de maior prestígio e valorização no mercado de trabalho local - quanto por se mostrar menos afetada pela "modernização súbita e intensa" (Fernandes, 2007, p. 66), tendeu a se mostrar como um "nicho" social (Hacking, 1998) em que as formas de identidade baseadas no isolamento da "cor", como núcleo de uma política de diferenças, não tiveram tanta capilaridade, nem mereceram tanta ênfase da parte de sua população negra e mestiça. De modo que, na Bahia, e particularmente em Salvador, em razão de sua demografia cultural africana singular no contexto brasileiro, mobilizar a cor, positivar, lançar ou invocar a raça entre suas "elites de cor" deveria parecer, talvez, tão improvável ou ofensivo quanto dizer que eles não passavam de um negro e, de alguma forma, de um africano ${ }^{53}$.

\footnotetext{
53 "Na Bahia, ao contrário, a fraca industrialização, a força demográfica dos descendentes de africanos, assim como a precariedade do sistema público de ensino, parecem ter servido para manter a opção de muitos negros pela preservação de sua tradição cultural como via de integração. Kim Butler explora muito bem essa dicotomia entre um movimento social negro que, em São Paulo, mobiliza-se em torno da 'raça' e um outro que, na Bahia, mobiliza a 'cultura africana'" (Guimarães, 2003b, pp. 21-22).
} 
Tais considerações não dão conta da complexidade dos esquemas de classificação étnicos da sociedade baiana de inícios do século XX, mas certamente nos ajudam a realizar um retrato aproximado da forma como a raça e a negritude foram vivenciadas por Édison Carneiro e sua família naquele momento. Foi em meio a um precipitado de experiências ambivalentes, ajustadas tanto às posições em falso da família entre os espaços das elites locais quanto às condicionantes históricas e culturais mais abrangentes da vida social baiana, que Édison Carneiro cumpriria uma etapa importante de seu aprendizado intelectual. Sem dúvida, extraiu daí repertórios, percepções e ângulos de visão sobre a sociedade baiana e brasileira que, em maior ou menor medida, desaguariam e estariam presentes em sua produção como estudioso da cultura e religiosidade de origem africana no Brasil.

\section{Gustavo Rossi}

é doutor em Antropologia Social pela Unicamp.

\section{Referências bibliográficas}

ALVES, M. 1977. Intelectuais e escritores baianos: breves biografias. Salvador:

Fundação Museu da Cidade.

AMADO, J. 1981. "O professor Souza Carneiro". A Tarde, 20 jun. 1985. "Discurso de Jorge Amado". A Tarde, 6 mar.

1992. Navegação de cabotagem: apontamentos para um livro de memórias que jamais escreverei. Rio de Janeiro: Record.

AZEVEDO, C. M. M. 2004. Antirracismo e seus paradoxos. São Paulo: Annablume. AZEVEDO, T. 1966. "Classes sociais e grupos de prestígio". In: Cultura e situação racial no Brasil. Rio de Janeiro: Civilização Brasileira.

[1953] 1996. As elites de cor numa cidade brasileira. Salvador:

Ed.UFBA.

BACELAR, J. 2001. A hierarquia das raças. Rio de Janeiro: Pallas.

BARRETO, L. 1998. Um longo sonho de futuro: diários, cartas, entrevistas e confissões dispersas. Rio de Janeiro: Graphia.

BARTH, F. 1998. "Grupos étnicos e suas fronteiras". In: POUTIGNAT, P.;

STREIFF-FENART, J. Teorias da etnicidade. São Paulo: Ed. Unesp. 
BASTIDE, R.; FERNANDES, F. 1958. Brancos e negros em São Paulo. São Paulo: Nacional.

BIAGGIO, T.; COUCEIRO, L. A. 2009. Édison Carneiro, o mestre antigo: um estudo sobre a trajetória de um intelectual. Salvador: Assembleia Legislativa do Estado da Bahia.

BRUBAKER, R. 2002. "Ethnicity without groups". European Journal of Sociology, vol. 43, no 2, pp.163-189.

CALMON, J. s.d. “A Academia de Letras da Bahia”. Disponível em <http:// www.academiadeletrasdabahia.org.br/academia/academia.htm $>$. Acesso em 20/12/2009.

CARNEIRO, E. 1943. "Souza Carneiro”. Revista Brasileira de Geografia, no 2, pp. 319-320 .

CARNEIRO, N. 1990. "Chefe”. In: Punhados de Vida. Brasília: Centro Gráfico do Senado Federal.

CARVALHO, M. A. R. 1998. O quinto século: André Rebouças e a construção do Brasil. Rio de Janeiro: Revan/Iuperj-Ucam.

2007. "Intelectuais negros no Brasil oitocentista". (mimeo).

COSTA, I. F. 2007. O rio São Francisco e a chapada Diamantina nos desenhos de Teodoro Sampaio. Dissertação de Mestrado em Ensino de Filosofia e História das Ciências. Salvador: UFBA/UEFS.

CUNHA, M. C. 1985. Negros estrangeiros: os escravos libertos e sua volta à África. São Paulo: Brasiliense.

1986. Antropologia do Brasil: mito, história, etnicidade. São Paulo: Brasiliense.

FARIAS, G. A. 1937. Memória histórica do ensino secundário da Bahia (18371937). Bahia: Imprensa Oficial do Estado.

FERNANDES, F. 2007. O negro no mundo dos brancos. São Paulo: Globo. 2008. A integração do negro na sociedade de classes. São Paulo: Globo (vol. 2).

FERRAZ, A. C. 1972. "Retrato de Édison Carneiro". A Tarde, 14 dez.

FIGUEIREDO, A. 2002. Novas elites de cor: estudos sobre profissionais liberais negros em Salvador. São Paulo: Annablume/CEAA.

FREYRE, G. [1936] 2003. Sobrados E̋ mocambos. São Paulo: Global.

GRINBERG, K. 2002. O fiador dos brasileiros: cidadania, escravidão e direito civil no tempo de Antônio Pereira Rebouças. Rio de Janeiro: Civilização Brasileira.

GUIMARÃES, A. S. 2003a.“A modernidade negra”. Teoria e Pesquisa, no 42-43, pp.41-62.

2003b. "Intelectuais negros e modernidade no Brasil". Working Paper 52. Centre for Brazilian Studies-University of Oxford. 
2004a. "Intelectuais negros e formas de integração nacional". Estudos Avançados, vol. 18, no 50, pp.271-284.

2004b. "Manoel Querino e a formação do 'pensamento negro' no Brasil, entre 1890 e 1920”. Texto apresentado no XXVIII Encontro da Anpocs. Caxambu (mimeo).

GUIMARÃES, R. 1973. "Breve esboço sobre a vida e a obra de Manuel Querino”. Revista Brasileira de Folclore, ano XII, no 35, pp.15-26.

HACKING, I. 1998. Mad travelers: reflections on the reality of transient mental illnesses. Virginia: Harvard University Press.

LANDES, R. [1947] 2002. Cidade das mulheres. Rio de Janeiro: Ed.UFRJ.

LIMA, V. C. 1987. "O Candomblé da Bahia na década de 30". In: OLIVEIRA, W. F. \& LIMA, V. C. (orgs.). Cartas de Édison Carneiro a Arthur Ramos de 4 de janeiro a 6 de dezembro de 1938. São Paulo: Corrupio.

LOPES, N. 2004. Enciclopédia brasileira da diáspora africana. São Paulo: Selo Negro.

MAGALHÃES, J. 1982. Minhas memórias provisórias: depoimento prestado ao CPDOC. Rio de Janeiro: Civilização Brasileira.

MALINOWSKI, B. 1978. Argonautas do Pacífico Ocidental. São Paulo: Abril Cultural.

MATTOSO, K. Q. 1992. Bahia século XIX: uma província no Império. Rio de 130 Janeiro: Nova Fronteira.

MICELI, S. 2001. "Intelectuais e classes dirigentes no Brasil (1920-1945)". In: Intelectuais à brasileira. São Paulo: Companhia das Letras.

NOGUEIRA, O. C. 1978. Caminhos de um magistrado. Rio de Janeiro: José Olympio.

NOGUEIRA, O. 1992. Negro político, político negro. São Paulo: Edusp.

1998. Preconceito de marca: as relações raciais em Itapetininga. São Paulo: Edusp.

OLIVEIRA, J. P. 2004. Pelas ruas da Bahia: criminalidade e poder no universo dos capoeiras na Salvador republicana (1912-1937). Dissertação de Mestrado em História. Salvador: UFBA.

OLIVEIRA, R. C. 1976. Identidade, etnia e estrutura social. São Paulo: Pioneira.

OLIVEIRA, W. F. 1987. "Os estudos africanistas na Bahia dos anos 30". In: OLIVEIRA, W. F. \& LIMA, V. C. (orgs.). Cartas de Édison Carneiro a Arthur Ramos de 4 de janeiro a 6 de dezembro de 1938. São Paulo: Corrupio.

PARDAL, P. 2001. "Primórdios do ensino de estatística no Brasil e na UERJ". Boletim de Associação Brasileira de Estatística, ano XVII, no 50 .

PIERSON, Donald. [1942] 1971. Brancos e pretos na Bahia: um estudo de contato racial. São Paulo: Companhia Editora Nacional.

PINHEIRO, E. P. 2002. Europa, França e Bahia: difusão e adaptação de modelos urbanos. Salvador: Ed. UFBA. 
PONTES, H. 2004. "A burla do gênero: Cacilda Becker, a Mary Stuart de Pirassununga”. Tempo Social, vol. 16, no 1, pp. 231-261. 2010. Intérpretes da metrópole. São Paulo: Edusp.

QUARESMA, M. S. 1999. O salvacionismo na Bahia: o político e a política de J. J. Seabra (1912-1916). Dissertação de Mestrado em História. Campinas: IFCH-Unicamp.

RAILLARD, A. 1992. Conversando com Jorge Amado. Rio de Janeiro: Record.

ROSSI, L. G. F. 2011. O intelectual feiticeiro: Édison Carneiro e o campo de estudos das relações raciais no Brasil. Tese de Doutorado em Antropologia Social. Campinas: IFCH-Unicamp.

SAMPAIO, C. N. 1998. Partidos políticos da Bahia na Primeira República: uma política da acomodação. Salvador: Ed. UFBA.

SANSONE, L. 2003. Negritude sem etnicidade: o local e o global nas relações raciais e na produção da cultura negra no Brasil. Salvador: Ed. UFBA.

SANTOS, G. (org.). 2005. Musa capenga: poemas de Édison Carneiro. Salvador: Fundação Cultural do Estado da Bahia.

SARMENTO, S. N. 2008. "A raposa e a águia: Rui Barbosa e J. J. Seabra na política baiana da Primeira República”. Texto apresentado no IV da ANPUH-BA. Vitória da Conquista (mimeo).

SEIXAS, C. 2005. "A poesia de Édison Carneiro redescoberta por Gilfrancisco”. In: SANTOS, G. (org.). Musa capenga: poemas de Édison Carneiro. Salvador: Fundação Cultural do Estado da Bahia.

SEM AUTOR. [1923] 2004. "Escola Politécnica e Instituto Politécnico da Bahia”. In: Diário Oficial do Estado da Bahia: edição comemorativa da Independência da Bahia (1923). Salvador: FPC/APEBa/Centro de Memória (edição fac-similar).

SEM AUTOR. s.d. "Fundação da Grande Loja Maçônica do Estado da Bahia - 1927”. Disponível em <http:/ /www.gleb.org.br/grande-loja>. Acesso em 20 abr. 2009.

SOUZA CARNEIRO, A. J. 1927. Jesus! Mistérios das iniciações de Jesus de Nazareth. São Paulo: O Pensamento.

1942. "Arlindo Fragoso", Revista da Academia de Letras da Bahia, vol. $8, \mathrm{n}^{\mathrm{o}} 16$.

SPTIZER, L. 2001. Vidas de entremeio: assimilação e marginalização na Áustria, no Brasil e na África Ocidental. Rio de Janeiro: Ed. UFRJ.

TEIXEIRA, C. 1988. “As oligarquias na política baiana”. In: LINS, W. et. al. Coronéis e oligarquias. Salvador: Ed. UFBA/Ianamá.

\section{Outros materiais}

CARNEIRO, E. 2008. Entrevista concedida ao autor. São Paulo, 18 abr. 


\section{UMA FAMÍLIA DE CULTURA: OS SOUZA CARNEIRO NA SALVADOR DE INÍCIOS DO SÉCULO XX}

\section{GUSTAVO ROSSI}

Resumo: A partir de uma etnografia histórica da sociedade baiana de inícios do século XX, o artigo trata da trajetória social e familiar do jornalista, etnógrafo e folclorista Edison de Souza Carneiro (1912-1972). O foco do texto é duplo: de um lado, reconstruir a posição social e política dos Souza Carneiro nos espaços das elites dirigentes de Salvador, atentando-se aos efeitos dessa posição na forma como questões relativas à raça e à negritude da família foram vivenciadas por seus membros, e, de outro, desvelar como estas coordenadas de natureza familiar, política e étnica rebateram nos primeiros experimentos intelectuais de Edison Carneiro, no final de década de 1920.

Palavras-chave: Edison Carneiro; Relações raciais; Família negra; Sociedade baiana; Salvador.

\section{A FAMILY OF CULTURE: THE SOUZA CARNEIROS IN SALVADOR OF THE EARLY TWENTIETH CENTURY}

Abstract: Based on an ethnography of the history of the early twentieth century Bahian society, the article addresses the social and familiar trajectory of the journalist, ethnographer, and folklorist Edison de Souza Carneiro (1912-1972). The paper's objectives are twofold: on the one hand, to reconstruct the social and political position of the Souza Carneiro family among the ruling elites of Salvador, especially regarding the effects of their race and blackness in their personal experience, and, on the other hand, to reveal how these familiar, political and ethnic experiences affected the early work of Edison Carneiro in the late 1920s. Keywords: Edison Carneiro; Race relations; Black family; Bahian society; Salvador.

Recebido: 05/08/2011 Aprovado: 03/10/2011 